NBER WORKING PAPER SERIES

\title{
THE STRUCTURE AND FORMATION OF BUSINESS GROUPS: EVIDENCE FROM KOREAN CHAEBOLS
}

\author{
Heitor Almeida \\ Sang Yong Park \\ Marti Subrahmanyam \\ Daniel Wolfenzon \\ Working Paper 14983 \\ http://www.nber.org/papers/w14983 \\ NATIONAL BUREAU OF ECONOMIC RESEARCH \\ 1050 Massachusetts Avenue \\ Cambridge, MA 02138 \\ May 2009
}

\begin{abstract}
Almeida is at the University of Illinois at Urbana-Champaign. Park is at Yonsei University, Subrahmanyam is at New York University, and Wolfenzon is at Columbia University. We wish to thank Utpal Battacharya, Mara Faccio, Radha Gopalan, Raghu Rau, Woochan Kim, Hannes Wagner, Luigi Zingales and participants at the 2008 WFA meetings, the 2008 NBER Summer Institute (Corporate Finance), 2008 EFA meetings, and seminars at Temple University, University of Minnesota, Notre Dame University, University of Texas at Austin, Washington University at St Louis, Indiana University, Purdue University, University of Toronto, University of Washington, Duke University, SIFR, FGV-Rio, and New York University for helpful comments. Ki Beom Binh, Yong Hyuk Choi, Jiyoon Lee and Andre De Souza provided outstanding research assistance. All errors are our own. The views expressed herein are those of the author(s) and do not necessarily reflect the views of the National Bureau of Economic Research.
\end{abstract}

NBER working papers are circulated for discussion and comment purposes. They have not been peerreviewed or been subject to the review by the NBER Board of Directors that accompanies official NBER publications.

(C) 2009 by Heitor Almeida, Sang Yong Park, Marti Subrahmanyam, and Daniel Wolfenzon. All rights reserved. Short sections of text, not to exceed two paragraphs, may be quoted without explicit permission provided that full credit, including $\mathbb{C}$ notice, is given to the source. 
The Structure and Formation of Business Groups: Evidence from Korean Chaebols Heitor Almeida, Sang Yong Park, Marti Subrahmanyam, and Daniel Wolfenzon NBER Working Paper No. 14983

May 2009

JEL No. G32,G34

\begin{abstract}
$\underline{\text { ABSTRACT }}$
In this paper we study the determinants of business groups' ownership structure using unique panel data on Korean chaebols. In particular, we attempt to understand how pyramids form over time. We find that chaebols grow vertically (that is, pyramidally) as the family uses well-established group firms ("central firms") to set up and acquire younger firms that have low profitability and high capital requirements. Chaebols grow horizontally (that is, using direct family ownership) when the family acquires firms that are highly profitable and require less capital. Our evidence suggests that the (previously documented) lower profitability of pyramidal firms is partly due to a selection effect (e.g., the family optimally places low profitability firms in pyramids). To show this, we examine instances of large changes in the ownership structure of group firms. Specifically, we find that poor past performance predicts an increase in the degree of pyramiding in a firm's ownership structure. Most compellingly, we find that the profitability of new group firms in the year before they are added to the group predicts whether they are added to pyramids or controlled directly by the family. We also examine the relative valuation of chaebol firms. We find that the group's central firms trade at a discount relative to other public group firms possibly due to the selection of low-profitability, high capital intensity firms into pyramids. Our results shed light on the process by which pyramids form, and provide new evidence on the performance and valuation of business group firms.
\end{abstract}

\author{
Heitor Almeida \\ University of Illinois at Urbana-Champaign \\ 515 East Gregory Drive, 4037 BIF \\ Champaign, IL, 61820 \\ and NBER \\ halmeida@illinois.edu \\ Sang Yong Park \\ Yonsei University \\ spark311@yonsei.ac.kr
}

\author{
Marti Subrahmanyam \\ Stern School of Business \\ New York University \\ msubrahm@stern.nyu.edu \\ Daniel Wolfenzon \\ Graduate School of Business \\ Columbia University \\ Uris Hall, Room 808 \\ 3022 Broadway \\ New York, NY 10027 \\ and NBER \\ dw2382@columbia.edu
}


Groups of firms under common ownership are prevalent around the world. These so-called business groups account for a large fraction of the economic activity of many countries. ${ }^{1}$ Most of these groups are controlled by families that hold equity stakes in group firms either directly or indirectly through other firms in the group. For example, one typical ownership structure is referred to as a pyramid. In this structure, the family achieves control of the constituent firms by a chain of ownership relations: the family directly controls a firm, which in turn controls another firm. ${ }^{2}$

The previous empirical literature has generally taken group structure as given, and studied the consequences induced by its ownership structure. The literature focuses mostly on the relationship between the controlling family's cash flow and voting rights and measures of accounting performance and valuation (see, e.g., Claessens, Djankov and Lang 2000, and Faccio and Lang, 2002). However, the reasons that determine a group's ownership structure remain largely unexplored. In particular, while there have been some recent theoretical attempts to understand pyramidal ownership, there is little empirical research that focuses on how pyramids form over time. ${ }^{3}$ We try to fill this gap in this paper.

Our tests draw mostly on Almeida and Wolfenzon's (2006) theory of pyramidal ownership. The key predictions of that theory refer to the characteristics of new firms that are placed by the family in pyramids. First, the higher the expected profitability of the new firm, the more likely it is that the family will control it directly, rather than create a pyramid. Direct ownership allows the family to avoid having to share the cash benefits of the new firm with shareholders of an existing group firm, which would have been the case had the family chosen to create a pyramid. There is also a financing advantage for the family in placing lower profitability firms in pyramids. To wit, the pyramidal structure allows the family to use the equity of existing group firms to invest in new firms. Group equity is particularly valuable when the family finds it harder to finance the new firm with external capital, for example if the new firm has low profitability. In addition, and for related reasons, the theory also predicts that firms that require larger capital expenditures should be placed in pyramids. Accordingly, our empirical tests examine the profitability and capital intensity of pyramidal firms, and compare them with firms that the family chooses to own directly.

The theory also makes two other predictions that we examine with our data. First, the theory suggests that firms owned through pyramids should be younger than other group firms (because the family uses existing group firms to set up and control new firms through pyramids). ${ }^{4}$ Second, the theory predicts that firms that are used by the family to set up

\footnotetext{
${ }^{1}$ Claessens, Fan, and Lang (2002) find that, in eight out of the nine Asian countries they study, the top 15 family groups control more that $20 \%$ of the listed corporate assets. In a sample of 13 Western European countries, Faccio and Lang (2002) find that, in nine countries, the top 15 family groups control more than $20 \%$ of the listed corporate assets.

${ }^{2}$ Pyramids are very common throughout the world. See, among others, Claessens, Djankov, and Lang (2000), for the evidence on East Asia, Faccio and Lang (2002) and Barca and Becht (2001) for Western Europe, Khanna (2000) for emerging markets, and Morck, Stangeland and Yeung (2000) for Canada.

${ }^{3} \mathrm{~A}$ recent paper by Fan, Wong and Zhang (2009) focuses on the formation of state-owned pyramids in China. As discussed by those authors, state-owned Chinese firms are special in that they show no separation between ownership and control. Bertrand et al (2004) use cross-sectional data on Thai business groups to study the role of family structure for group ownership structure and group firm performance. In particular, they find that groups that are controlled by larger families are more pyramidal in structure.

${ }^{4}$ As we discuss in Section 2, this implication is not trivial. For example, an alternative story is that
} 
and acquire other firms (firms that we call central firms) should trade at a discount relative to other public group firms. This is because the firms that the family decides to set up in a pyramid are the low profitability ones. The valuation discount arises because investors anticipate these low return investments by central firms.

We use a unique dataset of Korean business groups to test the theory's implications. The political and regulatory context of chaebols allows us to obtain extremely detailed ownership data on chaebol firms. Since the mid-1990s, the top Korean chaebols have had to report their complete ownership information to the Korean Fair Trade Commission (KFTC). These reports include ownership and accounting data on all firms (public or private) in each chaebol. Another feature that distinguishes our data is its dynamic nature. We have a panel from 1998 to 2004, for a relatively comprehensive sample of chaebol firms. In most countries, these type of data are not generally available. ${ }^{5}$

The theoretical arguments above motivate new metrics of group ownership other than the standard measures of cash flow and voting rights. First, we provide a measure of the position of any group firm relative to the controlling shareholder. This metric allows us to distinguish pyramidal from direct ownership. In addition, to identify firms that the family uses to set up new firms, we compute the centrality of a firm for the group structure (e.g., whether a given firm is used by the family to control other group firms). ${ }^{6}$ We also introduce a new metric to compute voting rights that we call critical control threshold. As we argue in the paper, the weakest link, the most common measure to compute voting rights, does not work well for groups with complex ownership structures. Our proposed measure can be seen as being closely related to the concept of weakest link and is easy to compute for any possible group structure. We provide algorithms that can generate these ownership measures for group structures of any degree of complexity. In our data, this is necessary because the complex ownership structures of Korean business groups (chaebols) with dozens of firms and several ownership links among them makes it difficult for the researcher to directly compute them. $^{7}$

We start by describing the basic characteristics of Korean chaebols. We find that both pyramids and cross-shareholdings are common in Korean chaebols. Nevertheless, pyramids in Korean chaebols are not "deep". A large majority of chaebol firms belong to pyramids with a total of two or three firms in the chain. Only a few group firms in each group are classified as being central, and they tend to be the older and larger firms in the group. These findings suggest that in a typical Korean chaebol, a small number of central firms hold stakes in a large number of firms controlled through a pyramid involving the central firms. We also observe a substantial number of firms that are controlled directly by the family, with no ownership links to other chaebol firms. This cross-sectional variation in chaebol firm ownership structures allows us to test the predictions described above.

pyramids arise as the family sets up firms with direct ownership, and uses them to acquire equity stakes in existing (e.g., older) group firms.

${ }^{5}$ Franks et al. (2008) assemble a dataset that contains ownership information on private firms in France, Germany, Italy and the UK. They focus on the trade-off between family and dispersed ownership, rather than on the ownership structure of groups.

${ }^{6}$ The measure of centrality that we derive is similar (but not identical) to that proposed by Kim and Sung (2006).

${ }^{7}$ Our algorithms can also be useful in other countries with complex ownership structures, such as India. 
The empirical evidence on the characteristics of group firms is largely consistent with the theoretical implications derived above. First, we find that firms owned through pyramids are younger than firms that are at the top of the group. Second, we find that firms that are placed at the bottom of the group (that is, that are controlled through pyramids) have lower profitability and higher capital expenditures than firms that the family chooses to place at the top of the group. Third, we find a robust negative correlation between centrality and marketto-book ratios (Tobin's $Q$ ). This valuation discount is consistent with the prediction that minority shareholders of the central firms "price in" the expected effect of value-destroying pyramidal investments.

A major challenge for our empirical tests is to distinguish our implications from the traditional argument that pyramidal ownership reduces firm performance (see, e.g., Claessens et al., 2002, and Joh, 2003), perhaps because of tunnelling incentives created by pyramiding (Bertrand, Mehta and Mullanaithan, 2002, Bae, Kang and Kim, 2002, Baek, Kang and Lee, 2006). To wit, a negative correlation between profitability and pyramidal ownership is consistent both with the selection story in Almeida and Wolfenzon, and also with the tunneling argument (which predicts that the family will tunnel profits away from pyramidal firms and towards firms in which it has higher cash flow ownership).

To show that the selection story is at work in the data, we perform several complementary tests. Our baseline empirical specification involves regressing a measure of the position of the firm in the group structure on its lagged profitability, while controlling for other variables that might explain the firm's position in the group such as firm age and size. First, we compute correlations between past profitability and position, separately for central and non-central firms. The selection story focuses on the choice of position for new non-central firms that are added to the group. In contrast, the tunneling argument should apply for both central and non-central firms. Second, we also include current profitability among the controls in some specifications. To the extent that profitability predicts position, the correlation between profitability and position should be stronger for lagged profitability. Third, we experiment with instances of large changes in a firm's position in the group. Examining large changes in position is useful because it allows us to rule out alternative explanations that rely on the fact that position does not change much over time. ${ }^{8}$ In particular, we examine whether low (high) past profitability predicts an increase (decrease) in the degree of pyramiding in a firm's ownership structure. Finally, we examine a sample of new firms that are added to chaebols in the time period of our sample, and study the determinants of their ownership structure. A firm's profitability in the year prior to becoming a chaebol firm cannot be affected by the ownership structure chosen later by the chaebol's controlling family. However, pre-chaebol profitability should explain the firm's ownership structure, according to the selection story.

Our results are consistent with the selection story. First, the correlation between past profitability and a firm's position in the chaebol is negative for non-central firms, but positive and insignificant for central firms. Second, the correlation is negative and significant for lagged profitability, but insignificant for current profitability. Third, poor past performance predicts an increase in the extent of pyramidal ownership in a firm's ownership structure. Finally, pre-chaebol profitability is strongly related to a firm's initial position in the group,

\footnotetext{
${ }^{8}$ For example, lagged profitability could be caused by the firm's lagged position, which happens to be the same as the current one.
} 
in a way that is consistent with theory - incoming low profitability firms are more likely to be placed lower down in pyramids. We note that these results do not rule out the possibility that the family tunnels cash flows out of firms that it decides to place in pyramids. The empirical tests are designed to identify the selection story, and not to provide direct evidence on the alternative tunneling story. For example, the fact that pre-chaebol profitability predicts the firm's first position in the group does not preclude the possibility that the family will tunnel cash flows away from pyramidal firms after they are placed in the group. However, our results do suggest that part of the correlation between pyramids and profitability that is documented in previous literature is likely to be due to reverse causality.

Overall, we believe that our paper contributes to the literature on business groups in four ways. Most importantly, our results shed new light on the process by which pyramids form. In addition, we present new results on the performance and valuation of business group firms. In particular, the central firm valuation discount is new to the literature. Third, we develop new metrics of group ownership structure (e.g., position, centrality and the critical control threshold) that can be useful for other researchers studying complex ownership structures in Korea and in other countries. Fourth, we use our metrics to describe and summarize the typical structure of a Korean chaebol. To our knowledge, this description is also new to the literature on Korean groups.

The outline of the paper is as follows. Section 1 provides a brief review of the literature on the financial performance of family groups. Section 2 develops the empirical implications that we test in this paper. Section 3 introduces our methodology to compute ownership variables for group firms. In Section 4 we describe our dataset. Section 5 presents our main empirical tests, and Section 6 concludes.

\section{Literature review}

There is a vast literature on family business groups. ${ }^{9}$ In this section, we discuss briefly the part of the literature that links ownership structure to financial performance.

The existing literature points out that the ownership structure of business groups is a potential determinant of group firm performance and valuation. ${ }^{10}$ Most papers use cash flows and voting rights as the main metrics to describe group structure. For example, Bertrand, Mehta and Mullainathan (2002) use a sample of Indian business groups to show that the value of group firms is affected by the controlling families' tunnelling of resources from firms in which they have low cash flow rights to firms in which their ultimate stake is high. ${ }^{11}$ In the context of Korean chaebols, Baek, Kang and Lee (2006) argue that discounted equity

\footnotetext{
${ }^{9}$ For a detailed review, see Morck et al. (2005).

${ }^{10}$ This does not mean that ownership is the only dimension of group structure that is interesting. Khanna and Thomas (2005), for example, show that stock price comovement in Chilean firms is greater when directors overlap than when firms belong to the same pyramid. Bertrand et al. (2004) link group structure to the history of the familes of controlling shareholders. Marisetty and Subrahmanyam (2008) study IPO underpricing of stand-alone and group firms. See also Khanna (2000), and the survey by Khanna and Yafeh (2007).

${ }^{11}$ In contrast, Gopalan, Nanda and Seru (2006) examine intra-group loans in Indian business groups, and find little evidence of tunneling. They suggest that loans are used to support financially weaker firms in the group.
} 
issues are more likely when the controlling shareholder has higher ultimate ownership in the acquirer than in the issuer. Bae, Kang and Kim (2002) argue that intra-chaebol acquisitions transfer wealth from firms in which the family has low cash flow rights (typically the acquirer) to those in which the family has higher cash flow rights. ${ }^{12}$ Claessens et al. (2002) show that firm value is negatively related to the separation between ownership and control in East Asia, while Lins (2003) finds similar results for a sample of firms from the emerging markets. Joh (2003) finds that the separation between ownership and control is negatively related to profitability in Korea. ${ }^{13}$

Instead of focusing on measures of cash flow and voting rights, other papers examine variables that indicate whether a firm has some indirect (e.g., pyramidal) ownership. In particular, Claessens et al. (2002) and Volpin (2002) provide evidence that firms with indirect ownership have lower Tobin's $Q$ than other firms. In contrast, Masulis, Pham, and Zein (2008) find that Tobin's $Q$ is higher in pyramidal firms than in firms at the top of the group.

The literature has also examined whether group membership affect valuation (Khanna and Rivkin (2001), Khanna and Palepu (2000), Fisman and Khanna (2000), and Claessens, Fan and Lang (2002)). Khanna and Palepu (2000), for example, find a positive effect of group membership in their sample from India. Baek, Kang and Park (2004) focus on the effects of Asian crisis on Korean firms, and show evidence for a stronger impact of the crisis on chaebol firms. In a cross-country study, Masulis et al. (2008) find that, after controlling for group membership choice, groups help improve firm value.

Finally, the literature provides some evidence on the correlation between ownership variables and firm characteristics. In particular, there is evidence that firms that are owned through pyramids are smaller and younger than firms at the top of the group (those that own shares in other firms). Aganin and Volpin (2005) describe the evolution of the Pesenti group in Italy, and show that it was created by adding new subsidiaries to the firms the Pesenti family already owned, through carve-outs of existing group firms. One of their conclusions is that, in Italy, business groups expand through acquisitions when they are large and have significant cash resources. Claessens, Fan and Lang (2002) find that firms with the highest separation of votes and ownership (i.e., those most likely to be owned through pyramids) are younger than those with less separation. Pyramidal firms also seem to be associated with larger scales of capital investment (Attig, Fischer, and Gadhoum (2003)). Claessens, Fan and Lang (2002) also find that, in East Asia, group firms tend to be larger than unaffiliated firms. Bianchi, Bianco, and Enriques (2001) find similar evidence for Italy. ${ }^{14}$

\footnotetext{
${ }^{12}$ In a related fashion, Cheung, Rau and Stouraitis (2006) find that connected transactions between Hong Kong listed companies and their controlling shareholders (such as transfer of assets across firms under the shareholder's control) result in value losses for minority shareholders. Their sample includes both group and non-group firms.

${ }^{13}$ Bennedsen and Nielsen (2006) find that valuation is negatively related to the separation between ownership and control in Continental Europe, but also that profitability is unrelated to measures of separation in the same region.

${ }^{14}$ Kang, Park and Jang (2006a) also analyze the family's choice of ownership structure in chaebols. However, they focus on average ownership characteristics of the entire group rather than on characteristics of individual chaebol firms.
} 


\section{Hypotheses regarding the formation of pyramids}

The traditional informal explanation for pyramidal structures is based on the idea that families try to control as many firms as possible to enjoy private benefits of control. Pyramidal structures lead to a separation of cash flow from voting rights that allow these families to minimize their ultimate cash flow stake in the firms they control (see, e.g., Bebchuk, Kraakman and Triantis, 2000). ${ }^{15}$ According to this argument, pyramidal structures are only a device to achieve the desired separation of cash flow from control rights. As discussed by Almeida and Wolfenzon (2006), while pyramids are generally associated with large deviations from "one share-one vote", this pattern is not universal (see, e.g., Franks and Mayer, 2001). In addition, despite the fact that the family can also use dual class shares to separate ownership from control, the incidence of pyramids in different countries does not appear to be caused by restrictions on the use of dual-class shares (La Porta, Lopez-de-Silanes, and Shleifer, 1999). This evidence suggests that considerations other than the separation of cash flow from voting rights motivate the creation of pyramids.

Almeida and Wolfenzon (2006) present a model of pyramidal ownership that does not rely on separation between ownership and control. Similar to the traditional story, their model is based on the assumption that families can extract private benefits from the firms they control at the expense of minority shareholders. In the model, a family has the choice of setting up a new firm (call it firm B) either through a pyramid (that is, using an existing group firm to buy a controlling equity stake in the new firm) or directly (that is, buying the equity stake directly with the family's personal wealth). Under the pyramidal structure, firm $\mathrm{B}$ is owned by all the shareholders of the original firm (call it firm A). As a result, the family shares the cash benefits (but not the private benefits) of firm B with nonfamily shareholders of firm A. In addition, the family has access to all of the retained earnings (cash) of firm A to acquire equity stakes in firm B. Under direct ownership, nonfamily shareholders of firm A have no rights to the cash flows of firm B, and thus, the family captures all of its cash benefits. However, in this case, the family has access only to its share of the retained earnings in the original firm (for example, through dividend payments).

This argument generates a number of testable hypothesis. For example, firms with low investment requirements and/or high profitability are less likely to be set up in pyramids. External financing is less important for such firms, and thus, the ability to use the cash retained in firm $\mathrm{A}$ is less valuable for the family. In addition, high profitability firms generate higher cash benefits for minority shareholders, and hence, the family is more likely to choose a direct ownership structure for firm B to avoid sharing these benefits with the minority shareholders of firm A. Conversely, the family is more likely to select pyramidal ownership when firm B has low profitability and high investment requirements. For such firms, using the cash retained in firm A through an equity investment in firm B is beneficial for the family. ${ }^{16}$

\footnotetext{
${ }^{15}$ This argument goes back at least to the beginning of the 20th century: Berle and Means (1932) and Graham and Dodd (1934) use this argument to explain the creation of pyramids in the U.S. in the early 20th century.

${ }^{16}$ Gopalan, Nanda and Seru (2007) develop a theory of dividends in business groups that uses arguments that resemble those in Almeida and Wolfenzon (2006). In particular, they show how families can use dividends as a way of transferring cash across group firms to finance group investments. Their focus is on explaining
} 
In the theory, these arguments are valid irrespective of the degree of separation between family ownership and control in firm B. While we would expect firms owned through pyramids to show (on average) higher separation between ownership and control than firms owned directly by the family, the financing advantage of using a pyramid to control firm $\mathrm{B}$ is independent of the deviation between cash flow and voting rights in firm B. ${ }^{17}$ This is in contrast to the traditional arguments for pyramids which rely on the fact that pyramids exist to separate ownership from control.

The model also generates implications about the valuation of pyramidal investments by the shareholders of firm A. Since the family places low profitability, high private benefit firms in pyramids, minority shareholders of firm A should not expect high returns from pyramidal investments. For example, an unanticipated announcement of a pyramidal investment of significant size should generate a negative return for the shareholders of firm A. In addition, if shareholders anticipate significant future pyramidal investments by firm A, then they should discount the shares of firm A accordingly, to compensate for the expected effects of future pyramidal investments on its equity returns.

Finally, the model generates implications about the timing of pyramid creation. In the model, a pyramidal structure allows the family to use firm A's financial capacity to reduce the financing costs of setting up firm B. This argument implies that pyramids are created over time. As existing family firms build internal resources, it becomes more likely that they will be used to acquire new firms through pyramidal stakes. In other words, we expect firms that hold large equity stakes in other group firms (those that are like firm A in the model) to be older than the firms at the bottom of the pyramid (those that are like firm B).

We summarize this discussion with a list of the implications about the structure of business groups, which can be tested with our data on Korean chaebols:

Implication 1 Group firms that are used by the family to set up and acquire new group firms are older than firms at the bottom of the group.

Implication 2 When adding a new firm to the group, the controlling family places firms with low expected profitability in pyramids and directly controls firms with high expected profitability.

Implication 3 Group firms that are owned through pyramids are more capital intensive than group firms that are owned directly by the family.

Implication 4 Public group firms that are used by the family to set up and acquire new group firms should have lower valuations than public group firms that are not used to set up and acquire new group firms.

Implication 1 might seem trivial, but one can imagine situations in which it does not hold. The family can set up a new firm with direct family ownership, and use its equity to buy stakes in other group firms (thus placing it at the top of a pyramid). Also, controlling families

group dividend policy rather than ownership structure.

${ }^{17}$ In fact, Almeida and Wolfenzon (2006) show that this financing advantage exists even when the family can issue unlimited dual-class shares to set up firm B. 
sometimes set up shell companies to acquire stakes in other group firms in a tax-efficient manner. In these cases we would see younger firms at the top of pyramids.

Implication 2 is consistent with a negative correlation between pyramidal ownership and profitability. In fact, previous papers find strong evidence on this correlation (see Section 1). However, the interpretation so far has been that this association is evidence that pyramids reduce profitability because they induce tunneling behavior by the family (Bertrand, Mehta and Mullanaithan, 2002, Bae, Kang and Kim, 2002, Baek, Kang and Lee, 2006). In contrast, in our argument the correlation is driven by the opposite direction of causality: lower profitability firms are selected into pyramids. We provide a battery of empirical tests to provide evidence on the direction of causality suggested by implication 2 . It is important to note, however, that the empirical tests that we provide are not designed to prove or disprove the tunneling argument. In addition, we note that Implication 2 and the tunneling argument are not mutually exclusive. In fact, in Almeida and Wolfenzon's (2006) model, the family will ex-post divert more cash flows from firms that it decides to place in pyramids ex-ante (because its ultimate ownership stake in that firm is lower).

Regarding Implication 4, previous empirical studies focus on the relation between a firm's valuation and its own ownership structure. In contrast, Implication 4 focuses on the role the firm plays in the group. This implication is new to the literature on groups. The central firm valuation discount also bears some resemblance to other empirical findings in the finance literature including the "closed-end fund puzzle" (see, e.g., Shleifer, 2000) and the "parent company discount" (see, e.g., Cornell and Liu, 2001). We discuss the relationship between our findings and these previous findings after we present the empirical results (in Section 5.3.1).

\section{$3 \quad$ Metrics of group ownership structures}

In order to test the empirical implications described in Section 2, we develop some new metrics of group structure. Specifically, the theory models the family's choice of whether to set up a new firm as a partial subsidiary of an established firm, or to hold stakes directly. To capture this notion, we define the variable position. We also define the variable centrality to identify firms that the controlling family uses to set up and acquire new firms. In addition, we argue that the standard measure of voting rights (the weakest link) is difficult to apply to groups with complex ownership structures such as the Korean chaebols. We propose an alternative measure of control in a group, the critical control threshold, and provide an algorithm to compute it.

We provide formulae and simple algorithms to compute all the metrics we propose. This is crucial for the case of Korea, where the web of ownership relations among group firms can be quite complex. As an illustration of this complexity, in Figure 1, we have selected only 11 of the 27 firms that form part of the Hyundai Motor group and drawn its ownership structure as of 2004. Needless to say, computing ownership metrics in this group can be a daunting task. Importantly, the formulae we propose can easily deal with any type of ownership structure.

In Appendix A, we show a numerical example that illustrates the computation of several of the ownership variables described here, including position, the critical control threshold, 
and centrality.

\subsection{Ultimate cash flow rights, position and loops}

We start by considering a business groups with $N$ firms. We define the matrix of intercorporate holdings $A$ as follows:

$$
A=\left[\begin{array}{cccc}
0 & s_{12} & \ldots & s_{1 N} \\
s_{21} & 0 & \ldots & s_{2 N} \\
\vdots & \vdots & \vdots & \vdots \\
s_{N 1} & \ldots & s_{N N-1} & 0
\end{array}\right]
$$

where $s_{i j}$ is the stake of firm $i$ in firm $j$. We also define a vector with the direct stakes of the family in each of the $N$ firms: ${ }^{18}$

$$
\mathbf{f}^{\prime}=\left[\begin{array}{llll}
f_{1} & f_{2} & \cdots & f_{N}
\end{array}\right] .
$$

The key insight to derive all formulae in this section is to follow one dollar of dividends paid by firm $i$. We write the dividend as a vector of zeroes with a 1 in the $i$ th position, $\mathbf{d}_{i}^{\prime}$. The family receives $\mathbf{f}^{\prime} \mathbf{d}_{i}$ when the dividend is paid and group firms receive $A \mathbf{d}_{i}$. Now suppose group firms pay out to shareholders what they themselves receive as dividends from other companies, i.e., the new dividend is now $A \mathbf{d}_{i}$. The family receives an additional $\mathbf{f}^{\prime}\left(A \mathbf{d}_{i}\right)$ and the cash in group firms out of the original dollar paid is $A\left(A \mathbf{d}_{i}\right)=A^{2} \mathbf{d}_{i}$. A simple pattern emerges: After $n$ rounds of dividends, the cash position of group firms is $A^{n} \mathbf{d}_{i}{ }^{19}$

\subsubsection{Ultimate cash flow rights}

We can now compute the family's ultimate cash flow right in firm $i, u_{i}$, which is defined as the fraction of the dividend originally paid by firm $i$ that is (eventually) received by the family:

Proposition 1 The ultimate ownership of the family in each of the $n$ firms is given by $\mathbf{u}=\left[\begin{array}{llll}u_{1} & u_{2} & \ldots & u_{N}\end{array}\right]^{\prime}:$

$$
\mathbf{u}^{\prime}=\mathbf{f}^{\prime}\left(I_{N}-A\right)^{-1}
$$

where $I_{N}$ is the $N \times N$ identity matrix.

This formula is easy to use and can accommodate any group structure, regardless of its complexity. ${ }^{20}$ Brioschi, Buzzacchi, and Colombo (1989) use a different method to derive this formula. Essentially the formula works through the matrix of cross-shareholdings to arrive at the ultimate ownership. This is very much in the same spirit as input-output analysis (Leontieff, 1986) where the share of an industry or sector in the aggregate economy is being computed.

\footnotetext{
${ }^{18}$ For brevity, we refer to the controlling shareholder as the "family" in the ensuing discussion.

${ }^{19}$ This argument does not presume that dividends are actually paid. If the dollar is retained in firm $i$, the formulas will tell us the fraction of the dollar that is owned by the family and the other group firms (e.g., the cash flow rights of the family and group firms).

${ }^{20}$ Most papers in the literature compute cash flow right by multiplying the stakes along the ownership chain. This is correct under the assumption that no cross-shareholdings exist. Under this assumption, the chain multiplication formula is a special case of equation 3 .
} 


\subsubsection{Position}

Using the same idea, we can now compute the position of a firm in a group. We define position as the distance between the family and a firm in the group. For example, in the case of a simple pyramid with two firms, the firm at the top of the pyramid is in position 1 and the one at the bottom is in position 2. Since there might be multiple chains from a particular firm to the family, we weigh each chain by its importance in terms of the cash flows the family receives. Note that the family receives $\mathbf{f}^{\prime} \mathbf{d}_{i}$ from firm $i$ directly (position 1 ). It also receives $\mathbf{f}^{\prime} A \mathbf{d}_{i}$ from firm $i$ through chains that contain one intermediate firm (position 2 ) and so on. Therefore, the position of firm $i$ is defined by

$$
\operatorname{pos}_{i}=\frac{\mathbf{f}^{\prime} \mathbf{d}_{i}}{u_{i}} \cdot 1+\frac{\mathbf{f}^{\prime} A \mathbf{d}_{i}}{u_{i}} \cdot 2+\frac{\mathbf{f}^{\prime} A^{2} \mathbf{d}_{i}}{u_{i}} \cdot 3 \cdots=\sum_{n=1}^{\infty} \frac{\mathbf{f}^{\prime} A^{n-1} \mathbf{d}_{i}}{u_{i}} \cdot n .
$$

Simplifying this expression leads to: ${ }^{21}$

Proposition 2 The position of firm $i$ can be written as :

$$
\operatorname{pos}_{i}=\frac{1}{u_{i}} \mathbf{f}^{\prime}\left(I_{N}-A\right)^{-2} \mathbf{d}_{i}
$$

where $I_{N}$ is the $N \times N$ identity matrix.

\subsubsection{Loops}

While it is not the main focus of the empirical tests, we can also use these calculations to check whether a firm is part of a cross-ownership pattern and to compute the number of firms involved in this loop. Essentially, if a dividend paid by firm $i$ eventually reappears in firm $i$, then $i$ is part of a loop. Also, the number of chains that it takes for funds to reappear for the first time in firm $i$ measures the number of firms in the shortest loop, which we define as loop:

\section{Definition 1 Let}

$$
\operatorname{loop}_{i}=\min \left\{n \mid n \geq 1 \text { and } \mathbf{d}_{i}^{\prime} A^{n} \mathbf{d}_{i}>0\right\},
$$

then firm $i$ is in a loop if and only if loop $i<\infty$. The number of firms in the shortest loop firm $i$ is involved in is given by loop .

\subsection{Control rights and centrality}

The computation of control rights in a complex group is challenging because it is not clear what fraction of the votes held by intermediate firms is ultimately controlled by the family. The most frequently used measure in the literature is the weakest link, which is defined as

\footnotetext{
${ }^{21}$ Kang, Park and Jang (2006b) derive an alternative measure of a firm's position in a group based on whether a firm owns significant equity in other group firms, or whether other firms own a large fraction of the firm's equity. The first component of the definition creates a mechanical correlation with our centrality variable (defined below), and so we believe our definition is more appropriate to the general case of complex ownership structures.
} 
the minimum stake along the chain of control. This measure is intuitive for simple pyramids: the controlling family must have a better grip on the control of a firm that is higher up in the pyramid than over a firm lower down that is controlled via the initial one. Yet, this measure has some drawbacks. First, when there are multiple chains used to control a firm, the definition calls for adding up the minimums over all chains. The intuition for this is not as clear. Second, in groups where there are multiple chains leading to one firm, this definition can generate numbers above $100 \% .{ }^{22}$ Finally, the weakest link is not well defined for firms that are part of loops as there are infinite chains leading to these firms.

In light of these problems, we define our own measure of control, the critical control threshold. Essentially, the critical control threshold, or $C C$ in short, is the maximum control threshold for which the firm belongs to the set of firms controlled by the family. This new definition has several appealing features. First, it can be defined for any group structure, regardless of its complexity. Second, it is derived from clearly stated assumptions about the characteristics of control. Finally, it turns out that this measure is equivalent to the weakest link when cross-shareholdings and multiple links are absent (that is, for simple pyramids). ${ }^{23}$ In that sense, it is a reasonable generalization of that simple, intuitive concept.

\subsubsection{The set of firms controlled by the family}

To compute the set of firms controlled by the family, we make two assumptions:

Assumption 1 A family controls a firm if and only if it holds more than $T$ votes in it, directly or indirectly.

Assumption 2 The votes that a family holds in a firm are the sum of its direct votes, plus all the direct votes of firms under family control, where control is defined in Assumption 1.

This definition of control is a combination of the idea of a control threshold (Assumption 1), plus the assumption that, if a family controls a firm, it controls the votes that this firm holds in other firms.

The following proposition establishes the formal condition that the set of firms controlled by the family must satisfy (for a given control threshold $T$ ). Suppose we start the analysis with a set $N$, which contains the universe of all candidate firms that could be controlled by the family. For example, this set can represent all firms in a country, or a pre-identified subset of those firms. We then have:

Proposition 3 For a given threshold T, the set of firms controlled by the family is given by:

$$
C(T)=\left\{i \in N: f_{i}+\sum_{j \in C(T), j \neq i} s_{j i} \geq T\right\} .
$$

In Appendix B we describe an algorithm that can be used to find $C(T)$.

\footnotetext{
${ }^{22}$ Simple examples are available from the authors upon request.

${ }^{23}$ In particular, if cross-shareholdings and multiple links are absent or not very substantial the weakest link methodology can be used to compute control rights. For example, Faccio and Lang (2002) show that neither problem is very prevalent in Europe, justifying the use of the weakest link as a measure of control in their sample.
} 


\subsubsection{Critical control threshold: definition}

We can now define our measure of control rights:

Definition 2 For any firm $i \in N$, the critical control threshold is given by

$$
C C_{i}=\max \{T \mid i \in C(T)\}
$$

The critical control threshold is the highest control threshold that is consistent with family control of firm $i$. In other words, if the control threshold were higher than $C C_{i}$, then firm $i$ would not be part of the set of firms controlled by the family.

\subsubsection{Centrality of a firm for the control of the group}

In the empirical tests we need to identify group firms that the controlling family uses to set up and control new firms. We identify such firms as those that are important for the control of other firms. This leads to the following definition. ${ }^{24}$

Definition 3 We define the centrality of a firm $i$ as:

$$
\text { central }_{i}=\frac{\sum_{j \neq i} C C_{j}-\sum_{j \neq i} C C_{j}^{-i}}{\sharp N-1},
$$

where $C C_{j}^{-i}$ is the critical control threshold of firm $j$, computed as if firm $i$ held no shares in the other group firms.

In words, we compute the centrality of firm $i$ as the average decrease in $C C$ across all group firms other than firm $i$, after we exclude firm $i$ from the group. This computation essentially determines how central a firm is, by comparing the average critical control treshold with and without including the stakes the firm holds in other firms. This formula, as the previous ones, can be implemented for group structure, regardless of its complexity.

In order to show that the empirical results are not driven by the control proxy that we use, we also experiment with an alternative measure of centrality that is based only on the direct equity stakes that each firm holds in other group firms. If we let $A_{j}$ be the total assets and $E_{j}$ be the total equity of firm $j$, we have the following definition:

Definition 4 We define the aggregate equity stake of firm $i$ in other group firms as:

$$
\text { stake }_{i}=\frac{\sum_{j} s_{i j} E_{j}}{A_{i}},
$$

This measure is essentially the total size of the equity stake that firm $i$ holds in other group firms, normalized by the total assets of firm $i$. We normalize by the assets of firm $i$ because firm $i$ 's valuation is more likely to be affected when the equity stakes are large relative to the size of firm $i$.

\footnotetext{
${ }^{24}$ Kim and Sung (2006) compute a similar variable for Korea, using cash flow rights instead of voting rights. They show that their measure of centrality is inversely related to the probability that the firm goes public. In contrast, we show below that firms with a high centrality value are much more likely to be public in our sample.
} 


\subsubsection{Consistent voting rights}

Besides the weakest link, the previous literature has also used an alternative measure of voting rights, namely the sum of the direct stakes held by the controlling shareholder, and all stakes held by firms controlled by this shareholder (LaPorta et al., 1999, and Lins, 2003). ${ }^{25}$

Definition 5 Given a threshold $T$, the consistent voting rights of the family in firm $i \in C(T)$ are defined as:

$$
V R_{i}(T)=f_{i}+\sum_{j \in C(T), j \neq i} s_{j i}
$$

In words, to compute the sum of the votes held by the family in firm $i$, we simply add the direct votes held by the family in firm $i$ with all the votes held by other firms that belong to $C(T)$. Since we only count indirect votes of firms provided that they belong to the control set, this definition of voting rights is (internally) consistent. The $V R$ measure is also the measure that is used by Korean regulators to compute the separation between ownership and control in chaebol firms.

\section{Data Description}

This section describes the sources for the ownership, accounting and financial data that we use in this study.

\subsection{Ownership Data}

The ownership data for our study are from the Korean Fair Trade Commission (KFTC), which was established in 1981 with the purpose of regulating competition. In particular, the KFTC's stated goal is to deter excessive concentration of economic power in a small number of large companies, including chaebols. Among other regulatory constraints, the KFTC requires that chaebol firms report complete ownership data. Chaebols are required to report the status of affiliate shareholders and persons with special interest and the financial status of group companies as of April 1 of each year. Ownership data are recorded in detail. Shareholders are categorized into seven types; family owner, the relatives of family owner, affiliates, nonprofit affiliate, group officer, treasury stock, and others. In addition, our data contain the name, the holding quantity, and the ratio of common stocks and preferred stocks of each individual shareholder.

The KFTC's defines a chaebol in two steps. ${ }^{26}$ In the first step, the KFTC defines the set of firms that belong to a business group. There are two criteria for this. The first is based on

\footnotetext{
${ }^{25}$ Some researchers attribute the weakest link measure to the paper by La Porta et al. (1999), but, in fact, they use a different definition of voting rights which is closer to the $V R$ measure. Specifically, they measure indirect ownership in a firm $i$ as the percentage of votes that other group firms hold directly in firm $i$, provided that these other group firms are also controlled by the family (under control thresholds of either $10 \%$ or $20 \%$ ). See Table I in p. 478 of their paper.

${ }^{26}$ To be more precise, the KFTC's definition that we describe here is that of a large business group. A chaebol is a large business group that is controlled by a family. Because our sample contains only family controlled groups, we refer to chaebols and large business groups interchangeably.
} 
stock ownership. According to this criterion, a firm belongs to a business group if ownership by the controlling shareholder and related persons (relatives and other affiliated companies of the same business group) amounts to more than 30 per cent, excluding preferred shares. The second criterion is qualitative. Firms are also classified as belonging to a business group when the controlling shareholder exercises "controlling influence" over it. The latter criterion is further detailed to include cases of exchange of directors and managers, and also substantial business transactions between a firm that belongs to the business group and the company in question. Because this criterion of controlling influence is interpreted broadly, some companies legally belong to a group even though neither the families, nor other affiliated companies in the group own shares in those companies.

In the second step, some business groups are designated as chaebols based on size, which is defined as the value of the combined total assets of affiliated companies in the group. From 1987 to 2001, the KFTC annually designated the 30 largest business groups as chaebols. From 2002 onwards, the KFTC started using a new category by including any group with total combined assets greater than a certain cutoff in their definition of chaebol. Currently, these are business groups with combined assets greater than two trillion won. ${ }^{27}$

From the ownership and financial database that the KFTC has maintained, we obtained data for the period 1998-2004. We focus only on business groups with the ownership of a natural person (i.e., family business groups), and exclude other business groups such as government-controlled business groups. Our ownership data contains 3,545 firm-year observations.

\subsubsection{Summary statistics: ownership variables and firm characteristics}

Table 1 shows the average values for the ownership variables across all firm-years in our sample (Panel A), and the cross-correlation matrix (Panel B). We also include other firm characteristics that we use in the analysis.

Panel A shows that there are a total of 47 groups and 1085 firms that were present at some point in the sample between 1998 and 2004. The controlling family holds $13 \%$ of the cash flows of the median firm, but it holds substantially more votes according to our two alternative measures of voting power. The consistent voting rights measure (VR) yields the largest voting power. The family and the affiliate firms hold $68 \%$ of the votes of the median firm in the sample. In contrast, the critical control threshold (CC) of the median firm is $30 \%$.

The data also indicate a substantial degree of pyramiding in Korean chaebols (the median position of a firm is 2.06), but with substantial cross-sectional variation (for example, $25 \%$ of the firms show an average position lower than 1.40). The typical pyramid is not deep (the 75th percentile of the position variable is approximately 2.5). Thus, while many chaebol firms are owned through pyramids, most of the time there is only one intermediate firm between the firm in question and the family.

Regarding centrality, the main pattern is that only a few firms are central for the group structure. The 75th percentile of centrality is zero. Similarly, the median aggregate stake

\footnotetext{
${ }^{27}$ Based on the won/dollar exchange rate of 946 on March 9th, 2007, two trillion won amounts to approximately 2.1 billion US dollars.
} 
held by group firms in other firms is zero, and the 75th percentile is just $3.5 \%$. This statistic suggests that only a small fraction of firms hold substantial stakes in other firms.

Most chaebol firms are private (74\% of firm-years involve unlisted firms). The median chaebol firm is 13 years old and has 190 employees. Therefore, despite the presence of a few very large firms in the sample, a typical chaebol involves many firms that are small, young and privately held. The summary statistics also show that $25 \%$ of the firm-years involve firms in indirect cross-shareholding loops. ${ }^{28}$ The high incidence of cross-shareholdings underscores the importance of taking cross-shareholdings into account when computing the other ownership measures.

In Panel B, we present the simple correlations among the ownership variables and the other firm characteristics in Panel A. The correlations show that public firms, central firms and firms in cross-shareholding loops tend to be higher up in the group structure (negative correlation with position). These variables are also correlated among themselves, that is, central firms are more likely to be public and belong to loops. Regarding firm characteristics, central firms are on average older, larger, and more likely to be public than other group firms. The same pattern holds for cross-shareholdings, which are more common among public, larger, and older firms. Position, in turn, is negatively correlated with age, public status and the number of employees.

The measures of cash flow rights and separation between ownership and control display expected patterns. The family has higher ultimate ownership in private, and smaller firms. Position is highly positively correlated with both of the separation measures, indicating that firms in pyramids have higher separation between ownership and control.

\subsubsection{The typical structure of a Korean chaebol}

Figure 2 summarizes the statistics above by charting the ownership structure of the typical chaebol. We can think of a typical chaebol structure as being organized in three layers. Some firms (firms 1, 2 in the figure) are owned directly at the very top of the group (a position value close to 1), without ownership links to the other firms. The middle layer contains firms that belong to cross-shareholding loops, and also central firms (firms 3, 4 and 5). Unlike the firms in the top layer, firms in this middle layer hold equity stakes in other chaebol firms, including other firms in the middle layer and firms in the bottom layer (such as firms 6, 7, etc.). Central firms in the middle layer tend to be public, and they are, on average, larger and older than other chaebol firms. In the bottom layer, in contrast, we observe firms that are more likely to be private, smaller and younger. These firms do not own substantial stakes in other firms. Most chaebol firms belong to this bottom layer.

Overall, this snapshot of chaebol structure is largely consistent with the historical evolution of chaebols. Chaebols appear to have grown as the controlling family used successful (e.g., large, public) group firms to set up and acquire new group firms that are placed at the

\footnotetext{
${ }^{28}$ The fraction of firms participating in cross-shareholding loops may seem surprising, given the fact that Korean regulation prohibits direct cross-shareholdings in chaebols. However, out of the 893 firm-years in which firms are involved in cross-shareholdings, we find that $72 \%$ belong to loops involving three firms, $13 \%$ are in loops involving four firms, and 6\% are in loops involving five firms or more. Thus, Korean chaebols appear to circumvent the regulations prohibiting cross-shareholdings by creating loops of three and more firms.
} 
bottom of the group, i.e., those with high position values. ${ }^{29}$

\subsection{Accounting and financial data}

In addition to the data obtained from the KFTC, we also used two other databases developed by Korea Listed Companies Association (KLCA) and Korea Investors Service (KIS), respectively, to obtain additional financial information. KLCA and KIS's databases contain information not only on listed companies, but also some private firms that are subject to external audit. We follow the standard procedure of dropping the data on financial institutions (insurance, brokerage and other financial institutions), which comprise 316 firm-years of the 3,545 firm-years of the sample described in section 4.1. These firms are subject to specific regulations and accounting rules that make their financial statements less comparable to the other chaebol firms, which are mostly in the manufacturing sector.

To correctly measure the profitability of each individual chaebol firm, we need to ensure that reported figures are not affected by equity stakes that a chaebol firm holds in other firms. From 1999 onwards, the financial statements of Korean chaebol firms became subject to the equity method reporting rule. The basic idea behind this accounting rule is to record firm A's share of firm B's equity as an asset for firm A, and firm A's share of firm B's profits as a source of non-operating income for firm A. The financial statements contain enough information to allow us to back out the exact amount by which accounting figures have been adjusted because of these equity stakes. We use this information to calculate our measures of assets and profits for chaebol firms, which we denote "stand alone assets" and "stand alone profits". The details are provided in Appendix C.

There are similar issues involved in the computation of a measure of Tobin's Q for chaebol firms. The market value of a publicly-listed chaebol firm includes the value of the equity stakes that this firm holds in other chaebol firms, both listed and unlisted. However, adjusting for the value of equity stakes is more difficult because the market value of private firms (which comprise a large fraction of the sample) is not observable. Therefore, our preferred measure of valuation is a measure of $Q$ that is unadjusted for the value of equity stakes:

$$
Q=\frac{E V+\text { Book Value of Liabilities }}{\text { Book Value of Assets }}
$$

where $E V$ is the market value of equity.

To show that the results are not driven by mismeasurement, we also experiment with a measure of $Q$ that takes the value of equity stakes into account, "stand alone Q":

$$
Q_{s a}=\frac{E V+\text { Book value of liabilities - Value of equity stakes }}{\text { Stand alone assets }} .
$$

To compute $Q_{s a}$ we assume that private firms are valued at book value. Provided this assumption is correct, $Q_{s a}$ can be interpreted as the $Q$ that a group firm would have if it were valued as a stand-alone entity.

\footnotetext{
${ }^{29}$ Aganin and Volpin (2005) also report similar evidence for one particular Italian business groups (the Pesenti group).
} 


\subsubsection{Summary statistics: accounting and valuation data}

Table 2, panel A, reports the summary statistics for the accounting and valuation variables. Given data availability, we end up with a sample of 2,695 firm-years between 1998 and 2004. ${ }^{30}$ Our benchmark measure of profitability is stand-alone return on assets (ROA), defined as stand-alone profits divided by stand-alone assets. For comparison, we also report a measure of profitability unadjusted for the equity stakes (ordinary income by total assets). The average unadjusted measure overstates average profitability by a small amount. Stand-alone assets are lower than total assets because of the adjustment for equity stakes (approximately by $10 \%$ on average). Next, we present statistics on the two measures of $Q$ and the equity values that we use to compute them. There are a total of 823 firm-years available for public firms between 1998 and 2004. Notice that $Q_{s a}$ and $Q$ have very similar distributions. ${ }^{31} \mathrm{We}$ also use capital expenditures divided by stand-alone assets to measure capital intensity, and non-current liabilities divided by stand-alone assets to measure leverage. ${ }^{32}$

Panel B displays some of the correlations between the financial and ownership variables. None of the ownership variables seem to be strongly correlated to stand-alone $R O A$. Standalone assets are positively correlated with centrality and negatively correlated with position. $Q$ is negatively correlated with both centrality and separation between ownership and control, but only if such separation is measured using the $C C$ measure of control. Finally, notice that capital expenditures are positively correlated with position. Several of these correlation patterns will be confirmed in the more fully specified regressions that we present below.

\section{$5 \quad$ Empirical tests}

We start with the hypothesis about the relative age of group firms (Implication 1). Then we move on to the hypotheses that relate group structure to accounting and financial variables (Implications 2, 3 and 4).

\subsection{Historical evolution of group structure}

As explained above, theory suggests that pyramidal business groups are created as the controlling family uses existing group firms to set up and acquire new firms. In the context of Figure 2, Implication 1 suggests that firms in the bottom layer of the group (those with pyramidal ownership) should be younger than central firms. It is less clear whether firms in the top layer of the group (non-central firms with direct ownership) should also be younger

\footnotetext{
${ }^{30}$ The data are winsorized at the first and 99th perecentiles, both in terms of stand-alone return on assets and stand-alone Q.

${ }^{31}$ This is consistent with the results in Bohren and Michalsen (1994), who compute distortions due to double counting of value of firms with cross shareholdings in Norway. Valuation metrics such as priceearnings ratio are relatively unaffected by cross-shareholdings, since there is double counting in both the numerator and the denominator. In contrast, French and Poterba (1991) report a substantial effect on cross-shareholdings on price-earning ratios in Japan in the 1980s.

${ }^{32}$ Korean cash flow statements disaggregate gross investments in tangible assets (e.g., increase in buildings) from the liquidation of tangible assets (e.g., decrease in buildings). Our capital expenditure measure is the sum of all gross investment items minus the sum of all liquidation items (e.g., net capital expenditures).
} 
than the central firms. Note that the top layer can include young firms that the family chose to control directly, but also older firms that have not become central firms.

Consistent with Implication 1, the summary statistics in Table 1 suggest that central firms are older and pyramidal firms younger than other group firms. To provide additional evidence, we use two different specifications that relate age to the firm's placement in the group structure. First, we regress the centrality measure on firm's age. We include group dummies since we want to know whether, within each group, central firms are older. We also include year dummies and other firms characteristics (size and public status). In the second specification, we regress the firm's position on firm's age. In addition to the same set of controls used in the first specification, we also control for centrality. This regression allows us to compare the age of firms in the bottom layer of the group (which tend not to be central) with the age of firms owned directly by the family, while controlling for the correlation between centrality and age. All standard errors are clustered at the firm level.

Table 3 presents the results. The first regression shows that, within each group, older firms are more likely to be central. Age and centrality continue to be correlated even after controlling for other firm characteristics such as public status and size, which are also related to centrality. The age coefficient in column (2) implies that 15 additional years of age are associated with an increase in centrality of 0.012 , which is close to the average value of centrality in Table 1. ${ }^{33}$ Consistent with our expectations, public and larger firms are also more likely to be central. Columns (3) and (4) show that age is also related to position in a way that is consistent with Implication 1. The coefficient on age in column (4) implies that 15 years of age decrease position by approximately 0.2 , or $10 \%$ of the average position. Finally, notice that position is negatively related to age even after controlling for centrality (column (5)). This implies that even among non-central firms, those in lower tiers of the pyramid are, on average, younger than those at the top of the group. Overall, these results support Implication 1.

\subsection{Predicting group structure}

Implication 2 relates the profitability of group firms to their position in the group. Specifically, firms with lower profitability should be placed in the bottom layer of the group. However, the tunneling argument also predicts a negative correlation between position and profitability. Once a firm is placed in a low position in the group, its performance is expected to deteriorate as cash flows are tunneled to firms higher up in the group structure (in which the family retains larger ultimate ownership).

In this Section we present evidence that the first effect (selection) is at work. We start by replicating findings from the previous literature in our data by estimating a regression of profitability on the family's ultimate ownership. We then experiment with empirical models in which position is the endogenous variable. In particular, we attempt to isolate the effect of profitability on the family's decision about where to place a firm in the group using a battery of complementary tests.

\footnotetext{
${ }^{33}$ The coefficients on firm age are multiplied by one hundred.
} 


\subsubsection{Family ownership and profitability}

In order to examine the correlation between profitability and ownership measures, we use the following empirical model:

$$
\begin{aligned}
\text { Stand-alone } R O A_{i, t}= & \beta_{1} \text { Ownership Variable } \text { Vit }_{i t}+\boldsymbol{\beta C o n t r o l s ~}_{i t}+ \\
& +\sum_{j} \text { industry }_{j}+\sum_{t} \text { year }_{t}+\varepsilon_{i, t},
\end{aligned}
$$

where we use both ultimate ownership and the measures of separation between ownership and control as alternative ownership variables. The vector of controls include firm size (measured by the log of stand-alone assets), age and public status, and leverage. We control for size, age and public status because all these variables are correlated with ownership variables (see Tables 2 and 3), and because they could also be related to performance. Controlling for leverage is important because the profitability measure that we use is computed after interest payments. ${ }^{34}$ In some specifications, we also include other measures of group structure (namely centrality and cross-shareholdings) to examine their correlations with profitability. ${ }^{35}$ We also control for industry and year fixed effects. The industry classification corresponds roughly to a 2-digit SIC classification in the US (there are 45 different industries in the sample). In some specifications, we also include group fixed effects to measure within-group effects. The standard errors are clustered at the level of the firm.

The results are presented in Table 4. Column (1) shows the standard positive correlation between ultimate ownership and profitability. This correlation is robust to the inclusion of group dummies (column (4)). Interestingly, ultimate ownership appears to be more robustly related to profitability than the measures of separation between ownership and control. In columns (2) and (3), only separation $V R$ is negatively correlated with profitability, and the correlation is not robust to the inclusion of group dummies (column (5)). Notice also that centrality is negatively correlated with profitability, but cross-shareholdings is not (columns (7) and (8)). The control variables have signs that are consistent with expectations. In particular, larger firms have greater profitability, and highly-levered firms have lower profitability. These results show that we can replicate traditional findings based on the tunneling argument in our data.

\subsubsection{Pyramids, profitability and capital intensity}

In order to examine the family's choice of where to place a firm in the group structure, we experiment with empirical models in which position is the dependent variable. Theory predicts that the controlling family is more likely to place a firm in a pyramid (high position), if the firm has low profitability, and high capital requirements. However, the theory has no clear prediction about the relative profitability and capital intensity of the central firms (those at the middle layer of Figure 2). This observation suggests that the effect of profitability and

\footnotetext{
${ }^{34} \mathrm{An}$ alternative way of controlling for this effect is to use a "before-interest" profitability measure. All results presented in the paper are robust to this change.

${ }^{35}$ Since the position variable is highly correlated with ultimate ownership and separation variables, it does not make sense to include them together in the same specification.
} 
capital intensity on a firm's position should be particularly pronounced among non-central firms.

We begin by estimating the following empirical model for both non-central and central firms separately:

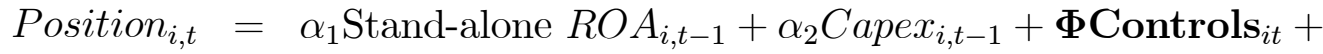

$$
\begin{aligned}
& +\sum_{j} \text { industry }_{j}+\sum_{t} \text { year }_{t}+\varepsilon_{i, t}
\end{aligned}
$$

Implication 2 suggests that the coefficient $\alpha_{1}$ should be negative, and Implication 3 suggests that the coefficient $\alpha_{2}$ should be positive. We use lagged accounting variables because the theory on group formation suggests that profitability and capital intensity should predict pyramidal ownership. We recognize, though, that simply lagging the performance variables is not sufficient to provide evidence on causality, and we address the issue of causality in greater detail below.

As a first stab towards providing evidence for selection, we also include current profitability (Stand-alone $R O A_{i, t}$ ) among the controls in some specifications. To the extent that profitability predicts position, the correlation between profitability and position should be stronger for lagged profitability than for current profitability. The other controls are identical to those used in Table 4 above (firm size, age, public status, leverage, and dummies for year, industry and group in some specifications). We divide the sample in central and non-central firms using the mean value of centrality as a cutoff. In other words, in the following tables "central firms" ("non-central firms") are those for which centrality is greater (lower) than its mean value of 0.02 (see Table 1 ).

The results are reported in Table 5. Columns (1) and (2) show that, for non-central firms, both lagged profitability and lagged capital expenditures are correlated with position in a way that is consistent with Implications 2 and 3, both before and after controlling for group fixed effects. Consistent with theoretical expectations, these correlations are largely absent in the sample of central firms (columns (3) and (4)). In particular, after controlling for group fixed effects, lagged profitability and capital expenditures have a positive and non-significant correlation with position in the sample of central firms. Columns (5) to (8) repeat the same regressions after including current profitability in the empirical model. Clearly, the negative correlation between profitability is position is driven by lagged profitability for non-central firms. Again, this pattern is consistent with a selection story in which the family places low profitability firms in pyramids. The control variables have the expected sign. For example, older and larger firms are more likely to be found at the top of the group.

\subsubsection{Does profitability predict pyramidal ownership?}

The negative correlation between lagged profitability of non-central firms and their position in the group structure reported in Table 5 is consistent with Implication 2 . However, these results may not be sufficient to rule out a reverse explanation due to tunneling. In this Section, we provide two additional tests that attempt to further distinguish between the selection and the tunneling stories. Both tests exploit the dynamic nature of our data, in that they both focus on large shocks to the group structure. 
Evidence from large changes in position One of the challenges in interpreting the results in Table 5 is that lagging profitability might not be sufficient to show that it influences firm's position because the position of an individual group firm does not vary much over time. It could also be the case that past profitability was determined by the firm's relative position in the group, which might be very similar to the current position. In fact, in most firm-years position changes very little. The $25 \%$ percentile of the distribution of annual firm-level changes in the position variable is -0.024 , while the $75 \%$ percentile is 0.04 . Thus, and not surprisingly, most of the variation in position is cross-sectional.

In order to provide additional evidence for the profitability selection story, we experiment with instances of large changes in a firm's position in a group. Specifically, we create dummy variables that capture cases in which a firm's position changed by more than 0.10 from one year to the next. This cutoff represents more than $10 \%$ of the total standard deviation in the position variable. ${ }^{36}$ The variable Position Increase takes the value of 1 if position increased by more than 0.10 from one year to the next, and zero otherwise (there are 388 firm-years that satisfy this criterion). The variable Position Decrease takes the value of 1 if position decreased by more than -0.10 from one year to the next, and zero otherwise (there are 278 firm-years that satisfy this criterion). We then replace the variable Position with Position Increase and Position Decrease in Equation 15. Since our dependent variable is a dummy we use a probit model for these regressions.

The results from these regressions are reported in the four first columns of Table 6 . Clearly, lagged profitability helps predict large changes in position in a way that is consistent with Implication 2. The first two columns show that low past profitability predicts increases in a firm's position in the group structure, both before and after controlling for group fixed effects. Thus, poor past performance predicts that a firm will be move to the bottom of the pyramid. High past profitability also predicts decreases in position after group dummies are included in the empirical model. This result suggests that high within-group performance predicts a change in group structure that moves a firm closer to the family, at the top of the group.

Evidence from new chaebol firms A different way to overcome the lack of time series variability in the position variable is to examine cases in which the family decides for the first time where to place a firm in the group structure. Specifically, there are 303 firms in our data that appear as chaebol firms for the first time in the sample window of 1998-2004. For 163 of these firms, we also have performance data the year prior to their inclusion. While the size of the sample is drastically reduced if we study only these firms, examining a firm's profitability before it is added to a chaebol allows for sharper tests of causality. To wit, if lower profitability does predict pyramidal ownership (Implication 2), then the relationship uncovered in Table 5 should also hold if we measure the firm's profitability before it became a chaebol firm. Presumably, a firm's profitability in the year prior to becoming a chaebol firm cannot be affected by the ownership structure chosen later by the chaebol's controlling family. However, pre-chaebol profitability should explain the firm's ownership structure,

\footnotetext{
${ }^{36}$ The results that we present are invariant to the particular cutoff used. We have also experimented with using changes larger than the mean change in position (0.03), or changes larger than certain percentiles of the distribution of the position variable ( $25 \%$ and $75 \%$ for example).
} 
according to Implication 2.

The last four columns of Table 6 contain the results. In columns (5) and (6), we run the regression in Equation (15) using only the sample of new chaebol firms. Low profitability continues to predict that a new firm will be controlled through a pyramid (high position), before and after including group dummies. These results suggest that when the family adds a new firm to the group that has low profitability relative to other group firms, it is more likely to place such a firm in a pyramidal structure. These results support the direction of causality suggested by Implication 2 (the selection story). The economic magnitude of the profitability effect also appears to be large. In column (5), for example, the estimates imply that a one standard-deviation decrease in profitability increases the firm's first position in the group by approximately 0.16 (which corresponds to $19 \%$ of the overall standard deviation of the position variable).

In columns (7) to (8), we perform two robustness checks. First, since the sample size is relatively small, we check whether the result is driven by a few outliers by winsorizing the data (both the position and the lagged profitability variables) at a $1 \%$ level. ${ }^{37}$ Column (7) shows that the results are unchanged. Second, our argument rests on the assumption that a firm's profitability in the year prior to becoming a chaebol firm cannot be affected by its ownership structure. Nevertheless, in some cases a firm might have been owned by another chaebol in the year prior to its acquisition, and through a pyramid. In these cases, the firm's lagged profitability might have been affected by its placement in a pyramidal structure. To ensure that this story does not explain our results, we eliminate all cases in which we can determine that a firm belonged to another chaebol in the year prior to its first appearance in a new chaebol. There are 16 of these cases. As column (8) shows, eliminating these firms does not affect the previous results.

\subsubsection{Discussion: predicting group structure}

Taken together, the results presented in Tables 5 and 6 suggest that profitability and capital expenditure requirements are correlated with past profitability in a way that is consistent with the selection hypothesis discussed in Section 2. The family appears to select low profitability firms, and firms with high capital expenditure requirements into pyramids. While the existing literature suggests an alternative explanation for the profitability results (that pyramiding reduces profitability), we present evidence consistent with the direction of causality suggested in Section 2 (low profitability predicts pyramiding).

We note that our results do not rule out the possibility that the family tunnels cash flows out of firms that it decides to place in pyramids. The empirical tests are designed to provide evidence for the selection implication, and not to directly test the alternative tunneling story. In order to do the latter (which is not our goal here), we would need an exogenous source of variation in ownership structure. We also note that the two stories are not necessarily mutually exclusive. For example, in Almeida and Wolfenzon's (2006) model, the family will ex-post divert more cash flows from firms that it decides to place in pyramids ex-ante (because its ultimate ownership stake in that firm is lower). However, our results do suggest is that profitability is also an important determinant of a firm's ownership structure.

\footnotetext{
${ }^{37}$ Results are identical if we winsorize at a $5 \%$ level instead.
} 


\subsection{Valuation and centrality}

We now test Implication 4 that central firms should trade at a discount relative to noncentral firms in the group. According to theory, this valuation discount is due to minority shareholders' anticipation of future pyramidal investments by central firms. We run the following regression:

$$
Q_{i, t}=\gamma_{1} \text { central }_{i, t}+\boldsymbol{\mu} \text { Controls }_{i t}+\sum_{j} \text { industry }_{j}+\sum_{t} \text { year }_{t}+\varepsilon_{i, t}
$$

where the controls include firm size (measured by the market value of total assets), age and public status, leverage, capital expenditures (to control for growth opportunities), and stand-alone $R O A$ (to control for current profitability). The previous literature reports some evidence that firms in which the family retains low ownership but high voting rights trade at discounts. Thus, in some specifications we control for measures of ownership concentration and separation between ownership and control. To measure centrality, we use both the benchmark measure (Equation (9)), and also the firm $i$ 's aggregate equity stake in other firms normalized by firm $i$ 's assets (Equation (10)). We also include a variable that measures whether a firm belongs to a cross-shareholding loop, because, as explained in Section 5.1, central firms also tend to be part of such loops. We control for industry and year fixed effects, and also for group fixed effects in some specifications. Standard errors are clustered at the firm level. Implication 4 suggests that the coefficient $\gamma_{1}$ should be negative.

Table 7 presents the results. Column (1) indicates that centrality is negatively related to firm valuation. The other variables have the expected signs. Larger and younger firms have higher $Q$, as do firms with high growth opportunities, proxied by their capital expenditures. There is also some indication that firms in cross-shareholding loops also trade at a discount, though this effect is not significant statistically. These results remain the same after controlling for ultimate ownership and the separation between ownership and control (columns (2), (3) and (4)). Interestingly, only the measure of separation based on the critical control threshold is significant in these regressions, with the standard negative sign that other papers in the literature have documented. In columns (5) to (8), we include group dummies. The correlation between centrality and valuation also holds within groups, suggesting that, in each group, central firms carry lower valuations than other group firms. These results support Implication 4.

The magnitude of central firms' valuation discount also appears to be significant. The distribution of the centrality variable is very modal (see Table 1), with $75 \%$ of the firms having a zero value for centrality, while a few firms (5\% of the sample) have centrality values greater than $10 \%$. If we look at these extremes, the coefficients on Table 7 (which range approximately from 0.4 to 0.6 ) imply that a firm with a centrality value equal to $10 \%$ would have a $Q$ that is $4.5 \%$ to $6.5 \%$ lower than a firm with zero centrality. ${ }^{38}$

We have also done some robustness checks to verify that the results in Table 7 are robust to our definition of centrality and valuation measures. The results are reported in the text. Given the difficulties in measuring control, which is a crucial component of our centrality measure, we also use the stake variable to measure centrality (see Equation 10). Given that

\footnotetext{
${ }^{38}$ This calculation assumes that other variables are evaluated at their unconditional averages, that is, the discount is $4.5 \%$ to $6.5 \%$ of average $Q$ (which is 0.9 in our data according to Table 2 ).
} 
the definition of stake is independent of our measure of control, these tests help alleviate concerns that the results are driven by the particular control measure we used. The results of our valuation regressions suggest that this is not the case - stake is also negatively and significantly related to firm valuation. In addition, we test whether our results are sensitive to our definition of $Q$. Given the difficulty to adjust $Q$ for the values of equity stakes (see Section 4.2), we used unadjusted $Q$ in our benchmark regressions. However, our robustness checks suggest that the results remain if we use $Q_{s a}$ (the implied stand-alone market-tobook ratio of chaebol firms) to value chaebol firms. In particular, centrality is negatively and statistically significantly related to $Q_{s a}$.

In addition to the systematic evidence, there are many examples of low valuation of central chaebol firms. A well known case is that of SK Corporation, the most central firm in the SK group. In December 2003, the market capitalization of SK Corporation (the largest oil refinery in Korea) was approximately 2.9 billion dollars. Besides several stakes in private group firms, SK Corporation had a stake of $20 \%$ on SK Telecom (the largest mobile telecom company in Korea), which was worth 13.6 billion dollars, and a $39 \%$ stake in SK Networks, which was worth 4.3 billion dollars. The value of these equity stakes alone (i.e., assuming a zero value for the stakes in private firms) was 4.4 billion dollars. Thus, the implied equity value of SK Corporation's stand alone assets was -1.5 billion dollars. One possible explanation for SK Corporation's negative equity value is that the firm had a large amount of liabilities (book value of liabilities equal to 8.1 billion dollars). If we add the entire amount of the book liabilities to SK Corporation's stand alone equity value, we obtain a stand alone market value of 6.6 billion dollars for SK Corporation. Under these assumptions, the implied stand-alone $Q\left(Q_{s a}\right)$ of SK Corporation was 0.68 in December 2003. The true $Q_{s a}$ was likely to be even lower, because the stakes in private firms are not worthless, and because the book value of liabilities probably overestimates the true market value of debt of SK corporation.

This relatively low valuation for SK Corporation attracted the interest of an activist investment fund that specializes in emerging market stocks (the Sovereign Fund), which amassed 15\% of SK Corporation shares in the market during 2003 and started issuing takeover threats. Sovereign's attack subsequently raised SK Corporation's equity value. As a result, by December 2004, SK Corporation's $Q_{s a}$ had increased to 0.92. The initial low valuation of SK Corporation is consistent with the argument that central firms should be discounted due to anticipated pyramiding. In addition, the increase in its market value after the Sovereign Fund amassed a large stake might be due to the market's realization that the large blockholder would prevent some of this pyramiding.

\subsubsection{Discussion: central firms' valuation discount}

The key characteristic of central firms is that they hold substantial equity stakes in other firms. Thus, the finding that central firms have low valuations bears some resemblance to the closed-end fund puzzle (see, i.e, Shleifer (2000)). Closed-end mutual funds tend to trade at substantial discounts relative to the NAV (net asset value) of the securities in their portfolios. ${ }^{39}$ In particular, some of the explanations developed to explain the closedend fund puzzle bear some resemblance to Implication 4. It is possible, for example, that

\footnotetext{
${ }^{39}$ See Rommens, Deloof and Jegers (2008), for related evidence using data from Belgian holding companies.
} 
shareholders of the closed-end fund expect poor portfolio management in the future (similar to Implication 4). Nevertheless, not all arguments regarding the closed end fund puzzle seem equally relevant. For example, the investor sentiment story explained in Shleifer (2000) applied to the chaebol context would require individual investors (who are more subject to fluctuations in sentiment when compared to institutional investors) to be more likely to hold and trade shares of the parent company, relative to the subsidiaries. Although we do not examine this issue directly in this paper, there is no reason to expect that condition to hold in the Korean data.

Cornell and Liu (2001), Mitchell, Pulvino and Stafford (2002) and Lamont and Thaler (2003) provide evidence on another phenomenon that bears some resemblance to the central firm discount (the "parent company discount"). For example, in the period of 1985-2000, Mitchell, Pulvino and Stafford (2002) identify 70 firms in which the market value of the equity stake that the parent holds in the subsidiary is higher than the market value of the parent. Lamont and Thaler (2003) show some extreme examples of potential misvaluations (such as the Palm and 3Com example), in which a commitment by the parent to spin-off the shares of the subsidiary at a fixed rate in a future date creates an apparently clear "arbitrage" opportunity. ${ }^{40}$ The standard explanation for this phenomenon in the US is that it is due to noise traders bidding up the prices of the subsidiary stocks, and arbitrage costs that make a price correction difficult to sustain (a large fraction of the firms analyzed in these studies are in the internet sector). We believe this market inefficiency story is also not likely to explain the central firm discount in Korea. First, the Korean phenomenon seems to be more general and persistent than the internet bubble-related discounts in the US. In particular, the subsidiaries of central Korean firms are not concentrated in any particular industry. Second, given the particular governance and ownership characteristics of Korean corporate finance, it seems a priori very likely that the valuation discount should be linked to agency issues related to family control of business groups rather than mispricing of chaebol firms. ${ }^{41}$

\section{Final remarks}

The main contribution of this paper is to shed new light on the process by which pyramids form. In doing this, we depart from the standard approach of assuming that ownership structure is exogenously given. We take advantage of a unique dataset that allows us to observe the details of the ownership structure of Korean chaebols, and to have a small window on how chaebol structure evolves over time. We see this paper as a first step towards the understanding of the evolution of business groups. Naturally, many questions are open for future research.

First of all, it would be interesting to see if our findings about group structure are particular to Korean chaebols or if they extend to groups in other countries as well. For that

\footnotetext{
${ }^{40}$ The spin-off fixed a ratio of shares of Palm that each 3Com shareholder would receive (1.5) in one year, subject to SEC approval. However, 3Com traded at a price that was substantially lower than 1.5 times the price of Palm. Ross (2004) offers a rational explanation for this phenomenon.

${ }^{41}$ Cornell and Liu (2001) discuss agency and liquidity explanations of US parent company discounts, and reject both possibilities in favor of the market inefficiency story above.
} 
purpose, we note that the metrics of ownership structure that we derive in the paper (such as the critical control threshold, position, and centrality) can be easily applied to other data. To facilitate the implementation of our measures, we provide algorithms that can be used to calculate these variables for groups of any complexity.

Second, while our short time series allows us to observe a few major changes in ownership structure (such as the addition of new firms to the group), there are many questions that require a longer time series. For example, besides observing that central firms are the most established firms in the group, we have little to say about how the family chooses central firms among several candidate group firms. Given that centrality changes little over time, addressing such a question requires a much longer time series than the one we currently have.

Last, but not least, we have focused exclusively on understanding the family's choice of ownership for chaebol firms, ignoring the question of why a given firm becomes a chaebol member in the first place. Clearly, understanding the selection of firms into chaebol is an essential component of a complete theory of business group structure. In addition, while we have taken the presence of cross-shareholdings into account to compute our ownership measure, we have not attempted to understand the reasons that motivate the family to create cross-shareholding loops among chaebol firms. Both of these questions could be analyzed in future research. 


\section{REFERENCES}

Aganin, Alexander, and Paolo Volpin, 2005, History of corporate ownership in Italy, in Randall Morck, ed.: The history of corporate governance around the world: Family business groups to professional managers (University of Chicago Press, Chicago, IL).

Almeida, Heitor, and Daniel Wolfenzon, 2006, A theory of pyramidal ownership and family business groups, Journal of Finance 61, p. 2637-2681.

Attig, Najah, Klaus Fischer, and Yoser Gadhoum, 2003, On the determinants of pyramidal ownership: Evidence on expropriation of minority interests, Working paper, Laval University.

Bae, Kee-Hong H, Jun-Koo Kang, and Jin-Mo Kim, 2002, Tunneling or value added? Evidence from mergers by Korean business groups, Journal of Finance 57, 2695-2740.

Baek, Jae-Sung, Jun-Koo Kang, and Kyung Suh Park, 2004, Corporate governance and firm value: evidence from the Korean financial crisis, Journal of Financial Economics 71, pp. 265-313.

Baek, Jae-Sung, Jun-Koo Kang, and Inmoo Lee, 2006, Business groups and tunneling: Evidence from private securities offerings by Korean chaebols, Journal of Finance pp. 2415-2449.

Barca, Fabrizio, and Marco Becht, 2001, The control of corporate Europe (Oxford University Press, Oxford).

Barontini, Roberto and Lorenzo Caprio, 2004, The effect of ownership structure and family control on firm value and performance: Evidence from Continental Europe, working paper, Università Cattolica del Sacro Cuore.

Bebchuk, Lucien, Kraakman, Reinier and George Triantis, 2000, Stock pyramids, crossownership, and dual class equity: The creation and agency costs of separating control from cash-flow rights, in Concentrated Corporate Ownership (R. Morck, ed.), pp. 445460.

Bennedsen, M. and K. Nielsen, 2007, The principle of proportional ownership, investor protection and firm value in Western Europe, working paper, Copenhagen Business School and CEBR.

Berle, Adolph A., and Gardiner C. Means, 1932, The modern corporation and private property, (McMillan, New York).

Bertrand, Marianne, Paras Mehta, and Sendhil Mullainathan, 2002, Ferreting out tunneling: An application to Indian business groups, Quarterly Journal of Economics 117, 121-148.

Bertrand, M., Johnson, S., Samphantarak, K. and Schoar, A., 2004, Mixing family with business: A study of Thai business groups and the families behind them, forthcoming, Journal of Financial Economics. 
Bianchi, Marcello, Magda Bianco, and Luca Enriques, 2001, Pyramidal groups and the separation between ownership and control in Italy, Working paper, Bank of Italy.

Bohren, Oyvind and Dag Michalsen, 1994, Corporate cross-ownership and market aggregates: Oslo Stock Exchange 1980-1990, Journal of Banking and Finance 18, 687-704.

Brioschi, Francesco, Luigi Buzzacchi, and Massimo G. Colombo, 1989, Risk capital financing and the separation of ownership and control in business groups, Journal of Banking and Finance 13, 747-772.

Cheung, Y.L., R. Rau and A. Stouraitis, 2006, Tunneling, propping, and expropriation: evidence from connected party transactions in Hong Kong, Journal of Financial Economics 82, p. 343-386.

Claessens, Stijn, Simeon Djankov, Joseph P.H. Fan, and Larry H.P. Lang, 2002, Disentangling the incentive and entrenchment effects of large shareholdings, Journal of Finance $57,2741-2771$.

Claessens, Stijn, Simeon Djankov, and Larry H.P. Lang, 2000, The separation of ownership and control in East Asian Corporations, Journal of Financial Economics 58, 81-112.

Claessens, Stijn, Joseph P.H. Fan, and Larry H.P. Lang, 2002, The benefits of group affiliation: Evidence from East Asia, Working paper, University of Amsterdam.

Cornell, Bradford, and Liu, Qiao, 2001, The parent company puzzle: When is the whole worth less than one of the parts?, Journal of Corporate Finance 7: 341-66.

Faccio, Mara, and Larry H.P. Lang, 2002, The ultimate ownership of Western European corporations, Journal of Financial Economics 65, 365-395.

Fan, Joseph, T.J. Wong, and Tianyu Zhang, 2009, Institutions and Organizational Structure: The Case of State-Owned Corporate Pyramids, working paper, Chinese University of Hong Kong.

Fisman, Raymond, and Tarun Khanna, 2000, Facilitating development: The role of business groups, Working paper, Columbia University and Harvard University.

Flath, David, 1992, Indirect shareholdings within Japan's business groups, Economics Letters 38: 223-227.

Franks, Julian, and Colin Mayer, 2001, Ownership and control of German corporations, Review of Financial Studies 14, 943-977.

Franks, Julian, Colin Mayer, Paolo Volpin and Hannes F. Wagner, 2008, Evolution of family capitalism: A comparative study of France, Germany, Italy and the UK. Working paper.

French, Kenneth R. and James M. Poterba, 1991, Were Japanese stock prices too high?, Journal of Financial Economics 29: 337-363. 
Gopalan, R., V. Nanda and A. Seru, 2006, Affiliated firms and financial support: Evidence from Indian business groups, Journal of Financial Economics 86 (3), 759-795.

Gopalan, R., V. Nanda and A. Seru, 2007, Do business groups use dividends to fund investments?, working paper.

Graham, Benjamin, and David L. Dodd, 1934, Security analysis (McGraw-Hill, New York.)

Holmen, Martin, and Peter Hogfeldt, 2004, Pyramidal power, Working paper, Uppsala University and Stockholm School of Economics.

Joh, Sung Wook, 2003, Corporate governance and profitability: Evidence from Korea before the economic crisis, Journal of Financial Economics 68, 287-322.

Kang, Hyung Cheol, Kyung Suh Park and Hasung Jang, 2006 a, The choice of group structure: Divide and rule, The Korean Journal of Finance 19: 188-230 (in Korean language).

Kang, Hyung Cheol, Kyung Suh Park and Hasung Jang, 2006b, Determinants of internal transactions among the member firms of Korean conglomerates, The Korean Journal of Finance 19: 77-118. (in Korean language)

Khanna, Tarun, 2000, Business groups and social welfare in emerging markets: Existing evidence and unanswered questions, European Economic Review 44, 748-61.

Khanna, Tarun, and Krishna G. Palepu, 2000, Is group affiliation profitable in emerging markets? An analysis of diversified Indian business groups, Journal of Finance 55, 867-891.

Khanna, Tarun, and Jan W. Rivkin, 2001, Estimating the performance effects of business groups in emerging markets, Strategic Management Journal 22, 45-74.

Khanna, Tarun and Caterine Thomas, 2005, Relationships and stock price comovements: Evidence from an emerging market. Working paper, HBS.

Khanna, Tarun and Yishay Yafeh, 2007, Business groups in emerging markets: Paragons or parasites? Forthcoming, Journal of Economic Literature.

Kim, W. and T. Sung, 2006, What makes group-affiliated firms go public? working paper, KDI School of Public Policy and Management.

La Porta, Rafael, Florencio Lopez-de-Silanes, and Andrei Shleifer, 1999, Corporate ownership around the world, Journal of Finance 54, 471-517.

Lamont, Owen, and Richard Thaler, 2003, Can the market add and subtract? Mispricing in tech stock carve-outs, Journal of Political Economy, p. 227-268.

Leontief, Wassily, Input-output economics, 2nd ed., New York: Oxford University Press, 1986. 
Lins, Karl V., 2003, Equity ownership and firm value in emerging markets, Journal of Financial and Quantitative Analysis 38, 159-184.

Masulis, Ronald, Peter Kien Pham, and Jason Zein, 2008, Pyramids: Empirical evidence on the costs and benefits of family business groups. Workig paper.

Marisetty, Vijaya, and Marti Subrahmanyam, 2008, Group affiliation and the performance of initial public offerings in the Indian stock market, Journal of Financial Markets, forthcoming.

Mitchell, Mark, Todd Pulvino, and Erik Stafford, 2002, Limited arbitrage in equity markets, Journal of Finance 57: 551-84.

Morck, Randall, David Stangeland, and Bernard Yeung, 2000, Inherited wealth, corporate control and economic growth: The Canadian disease, in Randall Morck, ed.: Concentrated Corporate Ownership (University of Chicago Press, Chicago, IL).

Morck, Randall, Daniel Wolfenzon, and Bernard Yeung, 2005, Corporate governance, economic entrenchment and growth, Journal of Economic Literature 43, 657-722.

Rommens, An, Marc Deloof and Marc Jegers, 2008, Why do holding companies trade at a discount? A clinical study, working paper.

Ross, S., 2004, Neoclassical Finance. Princeton University Press.

Shleifer, A., 2000. Inefficient markets: An introduction to behavioral finance. Oxford University Press.

Volpin, Paolo, 2002, Governance with poor investor protection: Evidence from top executive turnover in Italy, Journal of Financial Economics 64, 61-90. 


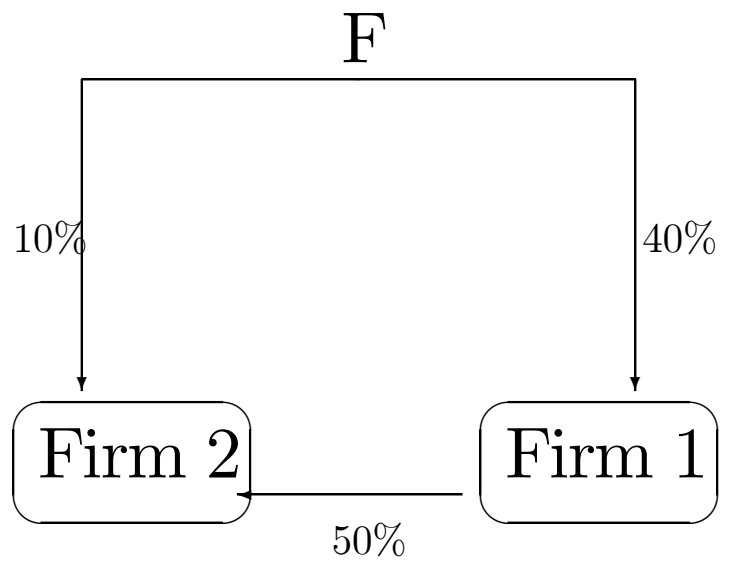

Figure A1: A simple group

\section{A Numerical examples of position, voting rights and centrality}

We illustrate the computation of our main ownership measures using a simple example. The group is represented in Figure A1. The family owns a 40\% direct stake in firm 1 and a $10 \%$ direct stake in firm 2. In addition, firm 1 owns a $50 \%$ stake in firm 2 . While this simple structure is not representative of real world chaebol structures, it can help the reader understand the logic behind the new measures.

\section{Ultimate ownership}

Ultimate ownership is easy to compute. The family's ultimate ownership in firm 1 is $40 \%$ and in firm 2 is $10 \%+(40 \%)(50 \%)=30 \%$.

\section{Position}

Firm's 1 position is clearly equal to 1 as there is only one chain leading to that firm. The formula we propose leads to the same answer: $\frac{4}{4} \cdot 1=1$. Regarding firm 2 , the family holds the direct stake of $10 \%$, and it also retains a $20 \%$ ownership stake through firm 1 . Our formula yields:

$$
\operatorname{pos}_{2}=\frac{0.1}{0.3} \cdot 1+\frac{0.2}{0.3} \cdot 2=1.7 \text {. }
$$

This is intuitive, since firm 2's ownership is close to a pure pyramid (the biggest stake is held through firm 1), but it is not a pure pyramid because of the direct stake of $10 \%$.

\section{Voting rights}

Take, for example, a control threshold equal to 30\% $(T=30 \%)$. In that case, the family controls firm 1 (since it holds $40 \%$ of its votes). According to our formula, the family has $50 \%$ of the votes in firm 2 (10\% directly and 50\% through firm 1 , which it controls). Thus, the family also controls firm 2. Clearly, the family controls both firms for any control threshold lower than or equal to $40 \%$. Thus:

$$
C(T)=\{1,2\} \text { for any } T \leq 40 \% .
$$


For $T$ above $40 \%$, the family no longer controls firm 1 . Also, the votes it controls in firm 2 are only $10 \%$ (we no longer add the $50 \%$ since for $T>40 \%$ the family does not control firm 1). Thus, the family does not control firm 2 either:

$$
C(T)=\emptyset \text { for any } T>40 \% .
$$

It follows that the critical control threshold measures are:

$$
C C_{1}=C C_{2}=40 \% \text {. }
$$

The $V R$ measures for any $T \leq 40 \%$ are:

$$
\begin{aligned}
& V R_{1}=40 \% \\
& V R_{2}=10 \%+50 \%=60 \% .
\end{aligned}
$$

The VR measure adds the entire stake held by firm 1 in firm 2 to the direct stake of $10 \%$, as long as the family retains control of firm 1 . If $T>40 \%, V R_{2}$ drops to $10 \%$.

\section{Centrality}

To compute centrality measures we compute the average critical control threshold with and without the relevant firm. Let's start with firm 2 . We know that $C C_{1}=40 \%$. If we eliminate firm 2 from the group and recompute $C C_{1}$, we would still have $C C_{1}=40 \%$. This implies that eliminating firm 2 from the group does not affect the average voting rights in other group firms. Accordingly, the centrality of firm 2 is 0 .

In contrast, if we eliminate firm 1 , the family will only control firm 2 if $T \leq 10 \%$. That is, $C C_{2}$ goes to $10 \%$. Thus:

$$
\text { central }_{1}=\frac{40 \%-10 \%}{1}=30 \% .
$$

\section{B Computing the set $C(T)$}

We first provide a formal definition of the algorithm to compute $C(T)$ and then we explain how it works.

Definition 6 (Algorithm) Let the sequence of sets $S(0) \supseteq S(1) \supseteq S(2) \ldots$ be defined by $S(0)=N$, and $S(n+1)=\left\{i \in S(n): f_{i}+\sum_{j \in S(n), j \neq i} s_{j i} \geq T\right\}$.

The idea behind this algorithm is to start with all the firms, $S(0)=N$. In the first stage, we assume that the family controls all the firms and we drop the firms in which the direct and indirect stake of the family is below $T$. This procedure generates $S(1)$. Next, we assume that the family controls only the firms in $S(1)$ and again drop from $S(1)$ the firms in which the direct and indirect stake of the family is below $T$. This generates $S(2)$. We can repeat this algorithm a number $\sharp N$ of times to arrive at $S(\sharp N)$. This last set is important in light of the following Proposition. 
Proposition $4 S(\sharp N)$ satisfies condition (7) which we re-write here:

$$
C(T)=\left\{i \in N: f_{i}+\sum_{j \in C(T), j \neq i} s_{j i} \geq T\right\} .
$$

A property that simplifies the algorithm is that if $S(n)=S(n+1)$ for $n<\sharp N$ then $S(\sharp N)=S(n)$. This means that we can stop the computation of the algorithm the first time we do not drop a firm.

To prove this proposition, we need to show $S(\sharp N)=\left\{i \in N: f_{i}+\sum_{j \in S(\sharp N), j \neq i} s_{j i} \geq T\right\}$. The proof is divided into a number of steps.

Step 1: $S(\sharp N)=S(\sharp N+1)$.

Consider two cases: 1) $S(\sharp N)=\varnothing$ and 2) $S(\sharp N) \neq \varnothing$. In case 1), the lemma follows directly from the definition of $S(\sharp N+1)$. In case 2$)$, we have that, after $\sharp N$ stages, there are firms that are not yet eliminated. Because we started with $\sharp N$ firms, this means that there was a stage $n \leq \sharp N$ such that no firm was dropped. In other words, we have that $S(n)=S(n-1)$. We can now compute $S(n+1)=\left\{i \in S(n): f_{i}+\sum_{j \in S(n), j \neq i} s_{j i} \geq T\right\}=$ $\left\{i \in S(n-1): f_{i}+\sum_{j \in S(n-1), j \neq i} s_{j i} \geq T\right\}=S(n)$, where the first equality follows from $S(n)=S(n-1)$ and the second from the definition of $S(n)$. Analogously, we can show that $S(n)=S(n+1)=S(n+2)=\ldots=S(\sharp N)=S(\sharp N+1)$. The last equality proves step 1 .

Step 2: $S(\sharp N) \subseteq\left\{i \in N: f_{i}+\sum_{j \in S(\sharp N), j \neq i} s_{j i} \geq T\right\}$

Note that $S(\sharp N)=S(\sharp N+1)=\left\{i \in S(\sharp N): f_{i}+\sum_{j \in S(\sharp N), j \neq i} s_{j i} \geq T\right\}$, where the first equality follows from step 1 and the second is simply the definition of $S(\sharp N+1)$. Because $S(\sharp N) \subseteq N$, it is clear that $i \in S(\sharp N) \Rightarrow i \in\left\{i \in N: f_{i}+\sum_{j \in S(\sharp N), j \neq i} s_{j i} \geq T\right\}$.

Step 3: $S(\sharp N) \supseteq\left\{i \in N: f_{i}+\sum_{j \in S(\sharp N), j \neq i} s_{j i} \geq T\right\}$

Towards a contradiction, we suppose that $k \in\left\{i \in N: f_{i}+\sum_{j \in S(\sharp N), j \neq i} s_{j i} \geq T\right\}$ and $k \notin S(\sharp N)$. The first condition implies that

$$
f_{k}+\sum_{j \in S(\sharp N), j \neq i} s_{j k} \geq T .
$$

The last condition implies that firm $k$ was eliminated in some earlier stage in the algorithm, say stage $n$. Thus $k \in S(n-1)$ but $k \notin S(n)$. We now have

$$
T>f_{k}+\sum_{j \in S(n-1), j \neq k} s_{j k} \geq f_{k}+\sum_{j \in S(\sharp N), j \neq k} s_{j k},
$$

where the first inequality follows from the fact that firm $k$ was eliminated in round $n$ and the second inequality follows from $S(n-1) \supseteq S(\sharp N)$ and the fact that $s_{i j} \geq 0$. This is a contradiction because Equations 21 and 22 cannot hold at the same time. Putting together steps 2 and 3 leads to the statement of the Proposition.

One problem that we need to address is the existence of multiple sets that satisfy condition 4. Consider the example in Figure A2, and assume that $T=25 \%$. Clearly, we have that $C(25 \%)=\{1,2,3\}$ because the set $\{1,2,3\}$ satisfies condition 4 . However, the null set also satisfies condition 4 for the same control threshold. To see this, suppose that the family 


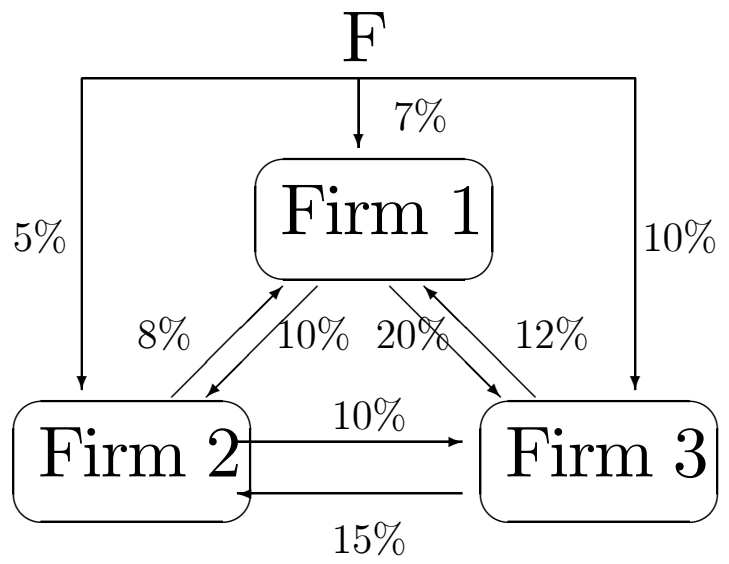

Figure A2: A complex group with many cross-shareholdings

controls no firms, then its voting rights in firms 1, 2 and 3 are $5 \%, 7 \%$, and 10\%, respectively. Note that all of them are below the threshold of $25 \%$, confirming that the family does not control any of these firms.

Because in the case of Korea the firms with which we start (the set $N$ ) have already been pre-classified as members of the chaebol, we would like to choose the set that satisfies Condition 7 and at the same time has the maximum number of firms. We can prove the following Proposition.

Proposition 5 Consider all possible sets of firms that satisfy condition 7 for a given control threshold $T: C_{1}, C_{2}, \ldots, C_{M}$. The following holds: $S(\sharp N)=\bigcup_{i=1}^{M} C_{i}$.

This proposition of important for two reasons. First, it tells us that there is a unique set that has the maximum number of firms over all the sets that satisfy Condition 7 . This is important since it removes the arbitrariness of picking a set among many. Second, the proposition tells us that the outcome of the algorithm is precisely the set we are looking for.

The proof of this result is divided into two steps.

Step 1: $S(\sharp N) \subseteq \bigcup_{i=1}^{M} C_{i}$

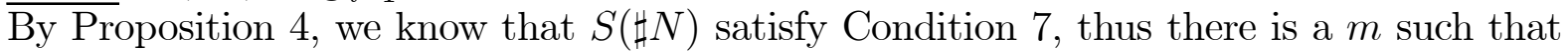
$S(\sharp N)=C_{m}$. The result follows.

Step 2: $S(\sharp N) \supseteq \bigcup_{i=1}^{M} C_{i}$

We show that $C_{m} \subseteq S(\sharp N)$ for all $m=1 \ldots M$. Step 2 follows directly from this. Take a set $C_{m}$. Because $C_{m}$ satisfies Condition 7 the following is true:

$$
\text { For all } k \in C_{m}, f_{k}+\sum_{j \in C_{m}, j \neq k} s_{j k} \geq T
$$

Towards a contradiction, suppose that some of the firms in $C_{m}$ are not in $S(\sharp N)$. That is, there must be a stage in the algorithm in which the first firm of $C_{m}$ is eliminated. Let 
that stage be $n$. We then have that $C_{m} \subseteq S(n-1)$ but there is at least one $k \in C_{m}$ such that $k \notin S(n)$. We now have that

$$
T>f_{k}+\sum_{j \in S(n-1), j \neq k} s_{j k} \geq f_{k}+\sum_{j \in C_{m}, j \neq k} s_{j k},
$$

where the first inequality follows from the fact that $k$ is eliminated in round $n$ and the second follows from $C_{m} \subseteq S(n-1)$ and the fact that $s_{j k} \geq 0$. This is a contradiction because Equations 23 and 24 cannot hold at the same time. This proves step 2. Finally, putting together steps 1 and 2 leads to the statement of the proposition.

\section{Accounting measures of stand-alone assets and stand- alone profits}

After January 1st, 2003, the item 'stocks accounted in equity method' (code number KLCA 123560) reports the aggregate book value of the shares subject to the equity method. Before 2003, however, 'stocks accounted in equity method' was not separately recorded but pooled into all investment securities. The data are available from the footnotes to financial statements, which we examined to calculate this item for the remaining years. Regarding profits, the profits coming from affiliate companies (call it "equity method profits") are recorded in two items in the non-operating portion of the income statement of parent companies. If equity method profits are positive, they are called "Gain on valuation of Equity Method" (KLCA \# 242100). If they are negative, they are called "Loss on valuation of Equity Method" (KLCA \# 252600).

With this knowledge, it is easy to adjust the financial statements to back out the values of the accounting figures that refer to each individual chaebol firm. Specifically, we have:

$$
\text { Stand-alone Assets = Total Assets - Equity Method Stock, }
$$

and:

Stand-alone Profits = Total Profits - Gains from Equity Method + Losses from Equity Method,

where we define stand-alone Assets/Profits as the asset/profit values that the chaebol firm would have in the absence of the equity method adjustment. These asset/profit figures reflect the individual assets and profitability of each chaebol firm.

One issue with the calculation of stand-alone profits is that one cannot easily back out the tax implications of the equity method adjustments. For example, if affiliate companies provide profits to a parent, the parent's taxes will be higher. However, we do not know exactly how much higher. Thus, in the calculations below, we use a pre-tax measure of profitability to measure each firm's Total Profits that we input in equation 26 (specifically, we use ordinary income to measure total profits).

We also check the data for basic consistency requirements. In particular, if the balance sheet shows a number for the equity method stock (i.e., if item KLCA\#123560 is nonmissing), then there should also be an item in the income statement for gains and losses 
from equity method (i.e., KLCA\#242100 and KLCA\#252600 cannot both be missing). The reverse should also hold. In addition, it should not be the case that both items KLCA\#242100 and KLCA\#252600 are positive, since affiliates will either generate a profit or a loss. We eliminate all firm-years that do not satisfy this consistency requirement. 


\section{Table 1: Summary Statistics of Ownership Variables and Firm Characteristics}

Panel A presents summary statistics of ownership variables of Korean chaebol firms for the period 1998-2004. Data is from the Korean Fair Trade Commission (KFTC). The variables are defined in detail the text (see Section 3). Ultimate ownership is a measure of the family's cash flow rights, and $V R$ (consistent voting rights) and CC (critical control threshold) are two alternative measures of voting rights. Separation CC and separation VR are defined, respectively, as CC minus ultimate ownership, and VR minus ultimate ownership. Position is a measure of the distance of a firm relative to the controlling family in the group structure. Centrality is the average drop in voting rights when a firm's votes are not taken into account to compute $C C$ for the other group firms. Stake is the book value of equity stakes held by a chaebol firm in other firms, normalized by assets. Cross-shareholdings takes a value of 1 if the firm belongs to a cross-shareholding loop. Public is a variable that takes the value of 1 if the firm is publicly traded. Panel B presents the correlation matrix for the variables summarized in Panel A.

Panel A: Basic Statistics

\begin{tabular}{lcccccc}
\hline \hline Variable & Mean & StDev & Median & $25 \%$ & $75 \%$ & Firm-years \\
\hline \hline Ultimate ownership & 0.21 & 0.22 & 0.13 & 0.05 & 0.28 & 3545 \\
VR & 0.68 & 0.28 & 0.68 & 0.47 & 1.00 & 3545 \\
CC & 0.33 & 0.19 & 0.30 & 0.19 & 0.43 & 3545 \\
Separation VR & 0.47 & 0.29 & 0.44 & 0.23 & 0.73 & 3545 \\
Separation CC & 0.12 & 0.11 & 0.12 & 0.03 & 0.19 & 3545 \\
Position & 2.11 & 0.82 & 2.06 & 1.40 & 2.56 & 3545 \\
Centrality & 0.02 & 0.05 & 0.00 & 0.00 & 0.00 & 3521 \\
Stake & 0.08 & 0.34 & 0.00 & 0.00 & 0.04 & 3545 \\
Cross-shareholdings & 0.25 & 0.43 & 0.00 & 0.00 & 1.00 & 3545 \\
Public & 0.26 & 0.44 & 0.00 & 0.00 & 1.00 & 3545 \\
Employees & 1198 & 3755 & 190 & 43 & 840 & 3545 \\
Firm age & 17 & 14 & 13 & 4 & 26 & 3545 \\
No.Firms & 1085 & & & & & \\
No.Groups & 47 & & & & \\
\hline \hline
\end{tabular}




\section{Table 1, cont.}

Panel B: Correlations among variables in Panel A

\begin{tabular}{|c|c|c|c|c|c|c|c|c|}
\hline & Ult Own & Separ VR & Separ CC & Position & Centrality & Cross-SH & Public & Employees \\
\hline Separation VR & -0.42 & & & & & & & \\
\hline Separation CC & -0.50 & 0.28 & & & & & & \\
\hline Position & -0.52 & 0.60 & 0.54 & & & & & \\
\hline Centrality & 0.10 & -0.25 & 0.06 & -0.26 & & & & \\
\hline Cross-SH & -0.06 & -0.20 & -0.04 & -0.18 & 0.21 & & & \\
\hline Public & -0.16 & -0.44 & 0.06 & -0.23 & 0.37 & 0.42 & & \\
\hline Employees & -0.09 & -0.18 & 0.01 & -0.16 & 0.24 & 0.30 & 0.35 & \\
\hline Firm age & 0.01 & -0.33 & -0.04 & -0.31 & 0.39 & 0.46 & 0.59 & 0.32 \\
\hline
\end{tabular}




\section{Table 2: Summary Statistics of Accounting and Financial Variables}

This table presents summary statistics for financial and accounting variables for chaebol firms during 1998-2004. Insurance, pension firms and other financial institutions are excluded from the sample. Data is from KLCA (Korea Listed Companies Association) and KIS (Korea Investors Service). ROA is ordinary income divided by book assets. Stand-alone $R O A$ and assets are computed after an adjustment that takes into account the effect of equity stakes held in other chaebol firms (see Appendix C for details). See Eq. (12) and (13) for the definitions of $Q, Q s a$, and the stand-alone market value of equity (the numerator of Eq. (13)). Leverage is defined as non-current liabilities divided by stand-alone assets. Panel A presents summary statistics, and Panel B presents the correlations among these variables and the ownership measures described in Table 1.

Panel A: Basic Statistics

\begin{tabular}{lcccccc}
\hline \hline & Mean & StDev & $25 \%$ & Median & $75 \%$ & Firm-years \\
\hline \hline Stand-alone ROA & 0.263 & 0.124 & -0.008 & 0.030 & 0.088 & 2695 \\
ROA & 0.027 & 0.124 & -0.006 & 0.031 & 0.090 & 2695 \\
Assets (million USD) & 794 & 2,320 & 29 & 110 & 527 & 2695 \\
Stand-alone assets (million USD) & 714 & 2,029 & 27 & 103 & 489 & 2695 \\
Q & 0.917 & 0.324 & 0.734 & 0.838 & 0.994 & 823 \\
Qsa & 0.908 & 0.363 & 0.707 & 0.828 & 1.011 & 806 \\
Mkt value of equity (million USD) & 2,089 & 5,191 & 224 & 706 & 1,968 & 823 \\
Stand alone mkt value of equity (million USD) & 1,905 & 4,833 & 214 & 634 & 1,811 & 806 \\
Capital expenditures/stand-alone assets & 0.056 & 0.148 & 0.008 & 0.029 & 0.073 & 2601 \\
Leverage & 0.213 & 0.296 & 0.043 & 0.146 & 0.301 & 2644 \\
\hline \hline
\end{tabular}

Panel B: Correlations

\begin{tabular}{lccccc}
\hline \hline & $\begin{array}{c}\text { Stand-alone } \\
\text { ROA }\end{array}$ & $\begin{array}{c}\text { Stand-alone } \\
\text { assets }\end{array}$ & $\mathrm{Q}$ & $\begin{array}{c}\text { Capex I } \\
\text { stand-alone } \\
\text { assets }\end{array}$ & Leverage \\
\hline \hline Stand-alone assets & 0.045 & & & & \\
Q & 0.117 & 0.154 & & & \\
Capex/stand-alone assets & 0.076 & -0.005 & 0.246 & & \\
Leverage & -0.251 & 0.075 & -0.004 & 0.009 & 0.011 \\
Separation VR & -0.033 & -0.190 & -0.027 & 0.068 & 0.051 \\
Separation CC & -0.003 & 0.028 & -0.101 & 0.037 & -0.021 \\
Position & 0.037 & -0.137 & 0.082 & 0.139 & 0.068 \\
Centrality & -0.001 & 0.252 & -0.147 & -0.057 & 0.090 \\
Cross-shareholdings & -0.014 & 0.332 & -0.025 & -0.092 & \\
\hline \hline
\end{tabular}




\section{Table 3: Historical Evolution of Chaebol Structure}

This Table presents the tests described in Section 5.1, which examine the relative age of firms in the chaebol. The variables are defined in Table 1. Position is a measure of the distance of a firm relative to the controlling family in the group structure. Centrality is the average drop in voting rights when a firm's votes are not taken into account to compute the critical control threshold for the other group firms. Public is a variable that takes the value of 1 if the firm is publicly traded. The coefficients on firm age are multiplied by one hundred. The coefficients on Employees are multiplied by one thousand.

\begin{tabular}{|c|c|c|c|c|c|}
\hline & \multicolumn{5}{|c|}{ Dependent variable } \\
\hline & Centrality & Centrality & Position & Position & Position \\
\hline & (1) & (2) & (3) & (4) & (5) \\
\hline Firm age & $\begin{array}{c}0.142^{\star \star \star} \\
(8.14)\end{array}$ & $\begin{array}{c}0.082^{* * *} \\
(5.01)\end{array}$ & $\begin{array}{c}-1.722^{\star \star \star} \\
(-10.88)\end{array}$ & $\begin{array}{c}-1.287^{\star \star *} \\
(-6.00)\end{array}$ & $\begin{array}{c}-1.043^{\star * \star} \\
(-4.76)\end{array}$ \\
\hline Public & & $\begin{array}{c}0.024^{\star \star \star} \\
(4.66)\end{array}$ & & $\begin{array}{c}-0.152^{\star \star} \\
(-2.20)\end{array}$ & $\begin{array}{l}-0.099 \\
(-1.43)\end{array}$ \\
\hline Employees & & $\begin{array}{c}0.010^{* \star \star} \\
(3.21)\end{array}$ & & $\begin{array}{c}0.016^{\star \star \star} \\
(-3.23)\end{array}$ & $\begin{array}{c}-0.012^{\star * \star} \\
(-2.73)\end{array}$ \\
\hline Centrality & & & & & $\begin{array}{c}-2.707^{\star \star \star} \\
(-7.87)\end{array}$ \\
\hline Group fixed effects & Yes & Yes & Yes & Yes & Yes \\
\hline Year fixed effects & Yes & Yes & Yes & Yes & Yes \\
\hline Observations & 3521 & 3521 & 3545 & 3545 & 3545 \\
\hline R-squared & 0.23 & 0.28 & 0.30 & 0.31 & 0.33 \\
\hline
\end{tabular}

Robust standard errors in parentheses, clustered at the firm level

* significant at 10\%; ** significant at 5\%; *** significant at $1 \%$ 


\section{Table 4: Family ownership and profitability}

This Table contains the tests described in Section 5.2.1, which relate a firm's profitability to family ownership variables (Equation (14)). The dependent variable is Stand-alone ROA. Ln assets is the logarithm of the book value of assets. Public is a variable that takes the value of 1 if the firm is publicly traded. Leverage is defined as non-current liabilities divided by stand-alone assets. The coefficients on firm age are multiplied by one thousand. Separation CC and separation VR are defined, respectively, as CC (critical control threshold) minus ultimate ownership, and VR (consistent voting rights) minus ultimate ownership. Centrality is the average drop in voting rights when a firm's votes are not taken into account to compute the critical control threshold for the other group firms. Cross-shareholdings takes a value of 1 if the firm belongs to a cross-shareholding loop, and zero otherwise.

\begin{tabular}{|c|c|c|c|c|c|c|c|c|}
\hline & \multicolumn{8}{|c|}{ Dependent variable: Stand-alone ROA } \\
\hline & (1) & (2) & (3) & (4) & (5) & (6) & (7) & (8) \\
\hline Firm age & $\begin{array}{l}-0.407 \\
(-1.48)\end{array}$ & $\begin{array}{l}-0.306 \\
(-1.12)\end{array}$ & $\begin{array}{l}-0.286 \\
(-1.05)\end{array}$ & $\begin{array}{l}-0.155 \\
(-0.52)\end{array}$ & $\begin{array}{l}-0.128 \\
(-0.43)\end{array}$ & $\begin{array}{l}-0.112 \\
(-0.37)\end{array}$ & $\begin{array}{l}-0.307 \\
(-1.06)\end{array}$ & $\begin{array}{l}-0.096 \\
(-0.31)\end{array}$ \\
\hline Ln assets & $\begin{array}{l}0.008^{* \star *} \\
(2.76)\end{array}$ & $\begin{array}{l}0.007 \text { ** } \\
(2.40)\end{array}$ & $\begin{array}{l}0.007 \text { ** } \\
(2.33)\end{array}$ & $\begin{array}{l}0.007^{* *} \\
(2.13)\end{array}$ & $\begin{array}{l}0.007^{* *} \\
(2.08)\end{array}$ & $\begin{array}{l}0.007 \text { ** } \\
(2.13)\end{array}$ & $\begin{array}{l}0.009 * * * \\
(2.95)\end{array}$ & $\begin{array}{l}0.007^{* *} \\
(2.21)\end{array}$ \\
\hline Public & $\begin{array}{l}-0.004 \\
(-0.41)\end{array}$ & $\begin{array}{l}-0.013 \\
(-1.39)\end{array}$ & $\begin{array}{l}-0.006 \\
(-0.69)\end{array}$ & $\begin{array}{l}-0.001 \\
(-0.10)\end{array}$ & $\begin{array}{l}-0.009 \\
(-0.99)\end{array}$ & $\begin{array}{l}-0.004 \\
(-0.44)\end{array}$ & $\begin{array}{l}-0.002 \\
(-0.25)\end{array}$ & $\begin{array}{l}-0.001 \\
(-0.05)\end{array}$ \\
\hline Leverage & $\begin{array}{l}-0.104 \text { *** } \\
(-5.88)\end{array}$ & $\begin{array}{l}-0.103 \text { *** } \\
(-5.87)\end{array}$ & $\begin{array}{l}-0.103^{* * *} \\
(-5.93)\end{array}$ & $\begin{array}{l}-0.099 * * * \\
(-5.34)\end{array}$ & $\begin{array}{l}-0.099 * * * \\
(-5.31)\end{array}$ & $\begin{array}{l}-0.099 * * * \\
(-5.35)\end{array}$ & $\begin{array}{l}-0.103^{* * *} \\
(-5.79)\end{array}$ & $\begin{array}{l}-0.099 * * \\
(-5.28)\end{array}$ \\
\hline Ultimate ownership & $\begin{array}{l}0.058 \text { *** } \\
(3.98)\end{array}$ & & & $\begin{array}{l}0.044 \text { ** } \\
(2.49)\end{array}$ & & & $\begin{array}{l}0.063 \text { *** } \\
(4.21)\end{array}$ & $\begin{array}{l}0.05^{* * *} \\
(2.76)\end{array}$ \\
\hline Separation VR & & $\begin{array}{l}-0.023 \text { * } \\
(-1.77)\end{array}$ & & & $\begin{array}{l}-0.018 \\
(-1.37)\end{array}$ & & & \\
\hline Separation CC & & & $\begin{array}{l}-0.034 \\
(-1.30)\end{array}$ & & & $\begin{array}{r}-0.02 \\
(-0.67)\end{array}$ & & \\
\hline Centrality & & & & & & & $\begin{array}{l}-0.111 \text { ** } \\
(-2.40)\end{array}$ & $\begin{array}{l}-0.117 \text { ** } \\
(-2.14)\end{array}$ \\
\hline Cross-shareholdings & & & & & & & $\begin{array}{l}-0.001 \\
(-0.26)\end{array}$ & $\begin{array}{l}0.005 \\
(0.72)\end{array}$ \\
\hline Industry fixed effects & Yes & Yes & Yes & Yes & Yes & Yes & Yes & Yes \\
\hline Year fixed effects & Yes & Yes & Yes & Yes & Yes & Yes & Yes & Yes \\
\hline Group fixed effects & No & No & No & Yes & Yes & Yes & No & Yes \\
\hline Observations & 2643 & 2643 & 2643 & 2643 & 2643 & 2643 & 2620 & 2620 \\
\hline R-squared & 0.16 & 0.15 & 0.15 & 0.24 & 0.23 & 0.23 & 0.26 & 0.24 \\
\hline
\end{tabular}

Robust standard errors in parentheses, clustered at the firm level. * significant at 10\%; ${ }^{* \star}$ significant at $5 \% ;{ }^{* \star \star}$ significant at $1 \%$ 


\section{Table 5: Determinants of a Firm's Position in the Chaebol}

This Table contains the tests described in Section 5.2.2, which relate a firm's position in the group to firm characteristics (Equation (15)). Position is a measure of the distance of a firm relative to the controlling family in the group structure. Stand-alone ROA is defined in Table 2, and capex is capital expenditures / stand-alone assets. Ln assets is the logarithm of the book value of assets. Centrality is the average drop in voting rights when a firm's votes are not taken into account to compute the critical control threshold for the other group firms. Central (non-central) firms are those for which Centrality is greater (lower) than its mean value of 0.02. Public is a variable that takes the value of 1 if the firm is publicly traded. Leverage is defined as non-current liabilities divided by stand-alone assets. The coefficients on firm age are multiplied by one thousand.

\begin{tabular}{|c|c|c|c|c|c|c|c|c|}
\hline & \multicolumn{8}{|c|}{$\begin{array}{l}\text { Dependent variable: Position } \\
\text { Regression contains only: }\end{array}$} \\
\hline & \multicolumn{2}{|c|}{ Non-central firms } & \multicolumn{2}{|c|}{ Central firms } & \multicolumn{2}{|c|}{ Non-central firms } & \multicolumn{2}{|c|}{ Central firms } \\
\hline & (1) & (2) & (3) & (4) & (5) & (6) & (7) & (8) \\
\hline Stand-alone ROA t-1 & $\begin{array}{l}-0.388 \text { ** } \\
(-2.49)\end{array}$ & $\begin{array}{l}-0.303 \text { * } \\
(-1.87)\end{array}$ & $\begin{array}{l}-0.721 \\
(-1.42)\end{array}$ & $\begin{array}{l}0.153 \\
(0.36)\end{array}$ & $\begin{array}{l}-0.399 \\
(-2.60)\end{array}$ & $\begin{array}{l}-0.272 \text { * } \\
(-1.76)\end{array}$ & $\begin{array}{l}-0.565 \\
(-1.10)\end{array}$ & $\begin{array}{l}0.114 \\
(0.28)\end{array}$ \\
\hline Stand-alone ROA t & & & & & $\begin{array}{l}0.039 \\
(0.19)\end{array}$ & $\begin{array}{l}-0.118 \\
(-0.59)\end{array}$ & $\begin{array}{l}-0.451 \\
(-1.26)\end{array}$ & $\begin{array}{l}0.195 \\
(0.49)\end{array}$ \\
\hline Capex t-1 & $\begin{array}{l}0.310 * * \\
(2.37)\end{array}$ & $\begin{array}{l}0.344^{* \star \star} \\
(2.94)\end{array}$ & $\begin{array}{l}-0.214 \\
(-0.54)\end{array}$ & $\begin{array}{l}0.008 \\
(0.03)\end{array}$ & $\begin{array}{l}0.311 * \star \\
(2.37)\end{array}$ & $\begin{array}{l}0.341 * * \star \\
(2.93)\end{array}$ & $\begin{array}{l}-0.136 \\
(-0.33)\end{array}$ & $\begin{array}{l}-0.014 \\
(-0.04)\end{array}$ \\
\hline Firm age & $\begin{array}{l}-7.605 \\
(-2.46)\end{array}$ & $\begin{array}{l}-8.379 \\
(-2.58)\end{array}$ & $\begin{array}{l}1.784 \\
(0.53)\end{array}$ & $\begin{array}{l}8.109 \text { * } \\
(1.67)\end{array}$ & $\begin{array}{l}-7.602 \text { ** } \\
(-2.46)\end{array}$ & $\begin{array}{l}-8.366 \text { ** } \\
(-2.57)\end{array}$ & $\begin{array}{l}1.505 \\
(0.45)\end{array}$ & $\begin{array}{l}8.295 \text { * } \\
(1.67)\end{array}$ \\
\hline Ln assets & $\begin{array}{r}0.000 \\
(-0.01)\end{array}$ & $\begin{array}{l}-0.037 \\
(-1.45)\end{array}$ & $\begin{array}{l}-0.075 \\
(-1.57)\end{array}$ & $\begin{array}{l}-0.076 \\
(-1.30)\end{array}$ & $\begin{array}{r}0.000 \\
(-0.01)\end{array}$ & $\begin{array}{l}-0.037 \\
(-1.45)\end{array}$ & $\begin{array}{l}-0.074 \\
(-1.56)\end{array}$ & $\begin{array}{l}-0.076 \\
(-1.31)\end{array}$ \\
\hline Public & $\begin{array}{l}-0.038 \\
(-0.42)\end{array}$ & $\begin{array}{l}-0.003 \\
(-0.03)\end{array}$ & $\begin{array}{l}-0.337 * * \\
(-2.13)\end{array}$ & $\begin{array}{l}-0.448 \text { ** } \\
(-2.45)\end{array}$ & $\begin{array}{l}-0.038 \\
(-0.41)\end{array}$ & $\begin{array}{l}-0.003 \\
(-0.04)\end{array}$ & $\begin{array}{l}-0.328 * \star \\
(-2.10)\end{array}$ & $\begin{array}{l}-0.455 * * \\
(-2.45)\end{array}$ \\
\hline Leverage & $\begin{array}{l}-0.124 * \\
(-1.68)\end{array}$ & $\begin{array}{l}-0.109 * \\
(-1.67)\end{array}$ & $\begin{array}{l}-0.048 \\
(-0.17)\end{array}$ & $\begin{array}{l}-0.113 \\
(-0.54)\end{array}$ & $\begin{array}{l}-0.123 * \\
(-1.65)\end{array}$ & $\begin{array}{l}-0.112 \text { * } \\
(-1.69)\end{array}$ & $\begin{array}{l}-0.096 \\
(-0.33)\end{array}$ & $\begin{array}{l}-0.104 \\
(-0.49)\end{array}$ \\
\hline Industry fixed effects & Yes & Yes & Yes & Yes & Yes & Yes & Yes & Yes \\
\hline Year fixed effects & Yes & Yes & Yes & Yes & Yes & Yes & Yes & Yes \\
\hline Group fixed effects & No & Yes & No & Yes & No & Yes & No & Yes \\
\hline Observations & 1693 & 1693 & 391 & 391 & 1693 & 1693 & 391 & 391 \\
\hline R-squared & 0.28 & 0.45 & 0.41 & 0.67 & 0.28 & 0.45 & 0.42 & 0.67 \\
\hline
\end{tabular}

Robust standard errors in parentheses, clustered at the firm level. * significant at $10 \% ;{ }^{* *}$ significant at $5 \%$; ${ }^{* * *}$ significant at $1 \%$ 


\section{Table 6: Does Profitability Predict Pyramidal Ownership?}

This Table contains the tests described in Section 5.2.3. The variable Position Increase takes the value of 1 if position increased by more than 0.10 from one year to the next, and zero otherwise. The variable Position Decrease takes the value of 1 if position decreased by more than -0.10 from one year to the next, and zero otherwise. In columns (1) to (4) we use a probit model. The regressions in columns (5) to (8) use a sample of firms in the years in which they first appear as a member of a chaebol. In column (7) we winsorize the data (both position and the lagged ROA variables) at a $1 \%$ level. In column (8) we eliminate all cases in which we can determine that a firm was owned by a chaebol in the year prior to its inclusion in a chaebol as a new firm. Stand-alone ROA is defined in Table 2. Ln assets is the logarithm of the book value of assets. Position is a measure of the distance of a firm relative to the controlling family in the group structure. Public is a variable that takes the value of 1 if the firm is publicly traded. Leverage is defined as non-current liabilities divided by stand-alone assets. The coefficients on firm age are multiplied by one thousand.

\begin{tabular}{|c|c|c|c|c|c|c|c|c|}
\hline & \multicolumn{8}{|c|}{ Dependent variable: } \\
\hline & \multicolumn{2}{|c|}{ Position increase } & \multicolumn{2}{|c|}{ Position decrease } & \multicolumn{4}{|c|}{ Position } \\
\hline & (1) & (2) & (3) & (4) & (5) & (6) & (7) & (8) \\
\hline Stand-alone ROA t-1 & $\begin{array}{l}-0.891 \text { *** } \\
(-2.81)\end{array}$ & $\begin{array}{l}-1.112 \text { *** } \\
(-2.99)\end{array}$ & $\begin{array}{l}0.286 \\
(0.90)\end{array}$ & $\begin{array}{l}0.745 \text { * } \\
(1.90)\end{array}$ & $\begin{array}{l}-1.273 \text { ** } \\
(-2.52)\end{array}$ & $\begin{array}{l}-1.131 \text { * } \\
(-1.86)\end{array}$ & $\begin{array}{l}-1.078 \text { ** } \\
(-2.55)\end{array}$ & $\begin{array}{l}-1.211 \text { ** } \\
(-2.16)\end{array}$ \\
\hline Firm age & $\begin{array}{l}-4.490 \\
(-1.22)\end{array}$ & $\begin{array}{l}-3.696 \\
(-0.84)\end{array}$ & $\begin{array}{l}-3.139 \\
(-0.80)\end{array}$ & $\begin{array}{l}0.477 \\
(0.11)\end{array}$ & $\begin{array}{c}15.830 \text { * } \\
(1.91)\end{array}$ & $\begin{array}{c}20.800 \text { ** } \\
(2.34)\end{array}$ & $\begin{array}{c}15.700 \text { * } \\
(1.89)\end{array}$ & $\begin{array}{r}13.500 \\
(1.54)\end{array}$ \\
\hline Ln assets & $\begin{array}{l}0.064 \text { ** } \\
(2.09)\end{array}$ & $\begin{array}{l}0.024 \\
(0.67)\end{array}$ & $\begin{array}{l}0.031 \\
(1.05)\end{array}$ & $\begin{array}{l}-0.024 \\
(-0.71)\end{array}$ & $\begin{array}{l}0.029 \\
(0.44)\end{array}$ & $\begin{array}{l}-0.036 \\
(-0.57)\end{array}$ & $\begin{array}{l}0.033 \\
(0.49)\end{array}$ & $\begin{array}{l}0.003 \\
(0.04)\end{array}$ \\
\hline Public & $\begin{array}{l}0.021 \\
(0.16)\end{array}$ & $\begin{array}{l}0.030 \\
(0.22)\end{array}$ & $\begin{array}{l}-0.008 \\
(-0.07)\end{array}$ & $\begin{array}{l}-0.101 \\
(-0.84)\end{array}$ & $\begin{array}{l}-0.899 * \star \star \\
(-3.96)\end{array}$ & $\begin{array}{l}-0.981 \text { *** } \\
(-3.90)\end{array}$ & $\begin{array}{l}-0.890^{* * \star} \\
(-3.95)\end{array}$ & $\begin{array}{l}-0.790 \text { *** } \\
(-3.25)\end{array}$ \\
\hline Leverage & $\begin{array}{l}-0.108 \\
(-0.93)\end{array}$ & $\begin{array}{l}-0.236 \\
(-1.52)\end{array}$ & $\begin{array}{l}0.100 \\
(0.95)\end{array}$ & $\begin{array}{l}0.149 \\
(1.33)\end{array}$ & $\begin{array}{l}-0.410 \\
(-1.14)\end{array}$ & $\begin{array}{l}0.476 \\
(1.13)\end{array}$ & $\begin{array}{l}-0.362 \\
(-1.01)\end{array}$ & $\begin{array}{l}-0.552 \\
(-1.55)\end{array}$ \\
\hline Industry fixed effects & Yes & Yes & Yes & Yes & Yes & Yes & Yes & Yes \\
\hline Year fixed effects & Yes & Yes & Yes & Yes & Yes & Yes & Yes & Yes \\
\hline Group fixed effects & No & Yes & No & Yes & No & Yes & No & No \\
\hline Firms in sample & All & All & All & All & Additions & Additions & $\begin{array}{r}\text { Additions } \\
\text { Winsorized }\end{array}$ & $\begin{array}{l}\text { Additions } \\
\text { Not owned } \\
\text { by chaebol }\end{array}$ \\
\hline Observations & 1665 & 1461 & 1641 & 1606 & 163 & 163 & 163 & 147 \\
\hline R-squared & 0.08 & 0.16 & 0.06 & 0.17 & 0.51 & 0.70 & 0.50 & 0.54 \\
\hline
\end{tabular}

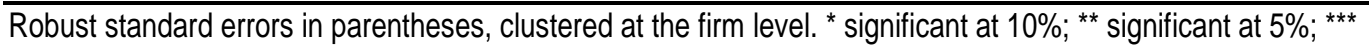




\section{Table 7: Valuation and Centrality}

This Table contains the tests described in Section 5.3, which relate a firm's valuation to firm characteristics (Equation (16)). The dependent variable is Tobin's Q, as defined in Eq. (12). Size is the log of the market value of equity. Centrality is the average drop in voting rights when a firm's votes are not taken into account to compute the critical control threshold for the other group firms. Separation CC and separation VR are defined, respectively, as CC (critical control threshold) minus ultimate ownership, and $V R$ (consistent voting rights) minus ultimate ownership. Leverage is defined as non-current liabilities divided by stand-alone assets. The coefficients on firm age are multiplied by one thousand.

\begin{tabular}{|c|c|c|c|c|c|c|c|c|}
\hline & \multicolumn{8}{|c|}{ Dependent variable: Q } \\
\hline & (1) & (2) & (3) & (4) & (5) & (6) & (7) & (8) \\
\hline Centrality & $\begin{array}{l}-0.545 \text { *** } \\
(-3.685)\end{array}$ & $\begin{array}{l}-0.470 * * \\
(-3.165)\end{array}$ & $\begin{array}{l}-0.564 \text { *** } \\
(-3.776)\end{array}$ & $\begin{array}{l}-0.515 \text { *** } \\
(-3.413)\end{array}$ & $\begin{array}{l}-0.401 \text { ** } \\
(-2.364)\end{array}$ & $\begin{array}{l}-0.382 \text { ** } \\
(-2.213)\end{array}$ & $\begin{array}{l}-0.392 \text { ** } \\
(-2.406)\end{array}$ & $\begin{array}{l}-0.402 \text { ** } \\
(-2.353)\end{array}$ \\
\hline Cross-shareholdings & $\begin{array}{r}-0.051 \\
(-1.585)\end{array}$ & $\begin{array}{r}-0.050 \\
(-1.553)\end{array}$ & $\begin{array}{r}-0.052 \\
(-1.587)\end{array}$ & $\begin{array}{r}-0.051 \\
(-1.546)\end{array}$ & $\begin{array}{r}-0.043 \\
(-1.035)\end{array}$ & $\begin{array}{r}-0.043 \\
(-1.037)\end{array}$ & $\begin{array}{r}-0.042 \\
(-0.997)\end{array}$ & $\begin{array}{r}-0.043 \\
(-1.034)\end{array}$ \\
\hline Firm age & $\begin{array}{l}-4.302 \text { *** } \\
(-3.700)\end{array}$ & $\begin{array}{l}-4.354 \text { *** } \\
(-3.744)\end{array}$ & $\begin{array}{l}-4.350 * * \\
(-3.672)\end{array}$ & $\begin{array}{l}-4.357 \text { *** } \\
(-3.722)\end{array}$ & $\begin{array}{l}-4.614 \text { *** } \\
(-3.345)\end{array}$ & $\begin{array}{l}-4.644 \text { *** } \\
(-3.385)\end{array}$ & $\begin{array}{l}-4.568{ }^{* * *} \\
(-3.239)\end{array}$ & $\begin{array}{l}-4.607 \text { *** } \\
(-3.334)\end{array}$ \\
\hline Size & $\begin{array}{l}0.089 \text { *** } \\
(6.464)\end{array}$ & $\begin{array}{l}0.085 \text { *** } \\
(5.902)\end{array}$ & $\begin{array}{l}0.089 \text { *** } \\
(6.485)\end{array}$ & $\begin{array}{l}0.089 \text { *** } \\
(6.467)\end{array}$ & $\begin{array}{l}0.091 \text { *** } \\
(5.368)\end{array}$ & $\begin{array}{l}0.091 \text { *** } \\
(5.320)\end{array}$ & $\begin{array}{l}0.091{ }^{* \star *} \\
(5.346)\end{array}$ & $\begin{array}{l}0.091 \text { *** } \\
(5.332)\end{array}$ \\
\hline Stand-alone ROA & $\begin{array}{r}0.077 \\
(0.315)\end{array}$ & $\begin{array}{r}0.087 \\
(0.346)\end{array}$ & $\begin{array}{r}0.077 \\
(0.315)\end{array}$ & $\begin{array}{r}0.076 \\
(0.310)\end{array}$ & $\begin{array}{r}0.188 \\
(0.830)\end{array}$ & $\begin{array}{r}0.189 \\
(0.827)\end{array}$ & $\begin{array}{r}0.187 \\
(0.825)\end{array}$ & $\begin{array}{r}0.189 \\
(0.831)\end{array}$ \\
\hline Capex & $\begin{array}{c}0.432 \text { * } \\
(1.942)\end{array}$ & $\begin{array}{c}0.442 \text { * } \\
(1.971)\end{array}$ & $\begin{array}{l}0.428 \text { * } \\
(1.926)\end{array}$ & $\begin{array}{l}0.419 \text { * } \\
(1.892)\end{array}$ & $\begin{array}{r}0.331 \\
(1.568)\end{array}$ & $\begin{array}{r}0.332 \\
(1.571)\end{array}$ & $\begin{array}{r}0.330 \\
(1.565)\end{array}$ & $\begin{array}{r}0.331 \\
(1.571)\end{array}$ \\
\hline Leverage & $\begin{array}{r}0.052 \\
(0.382)\end{array}$ & $\begin{array}{r}0.050 \\
(0.370)\end{array}$ & $\begin{array}{r}0.058 \\
(0.426)\end{array}$ & $\begin{array}{r}0.058 \\
(0.429)\end{array}$ & $\begin{array}{r}0.003 \\
(0.021)\end{array}$ & $\begin{array}{r}0.002 \\
(0.017)\end{array}$ & $\begin{array}{r}0.001 \\
(0.006)\end{array}$ & $\begin{array}{r}0.002 \\
(0.019)\end{array}$ \\
\hline Ultimate ownership & & $\begin{array}{r}-0.111 \\
(-1.169)\end{array}$ & & & & $\begin{array}{r}-0.061 \\
(-0.436)\end{array}$ & & \\
\hline Separation VR & & & $\begin{array}{r}-0.069 \\
(-0.813)\end{array}$ & & & & $\begin{array}{r}0.031 \\
(0.346)\end{array}$ & \\
\hline Separation CC & & & & $\begin{array}{c}-0.214 \text { * } \\
(-1.894)\end{array}$ & & & & $\begin{array}{r}0.014 \\
(0.117)\end{array}$ \\
\hline Industry fixed effects & Yes & Yes & Yes & Yes & Yes & Yes & Yes & Yes \\
\hline Year fixed effects & Yes & Yes & Yes & Yes & Yes & Yes & Yes & Yes \\
\hline Group fixed effects & No & No & No & No & Yes & Yes & Yes & Yes \\
\hline Observations & 807 & 807 & 807 & 807 & 807 & 807 & 807 & 807 \\
\hline R-squared & 0.42 & 0.42 & 0.42 & 0.42 & 0.52 & 0.52 & 0.52 & 0.52 \\
\hline
\end{tabular}

Robust standard errors in parentheses, clustered at the firm level. ${ }^{*}$ significant at $10 \% ;{ }^{* *}$ significant at $5 \% ;{ }^{* * *}$ significant at $1 \%$ 
Figure 1. Ownership Structure of Hyundai Motor in 2004

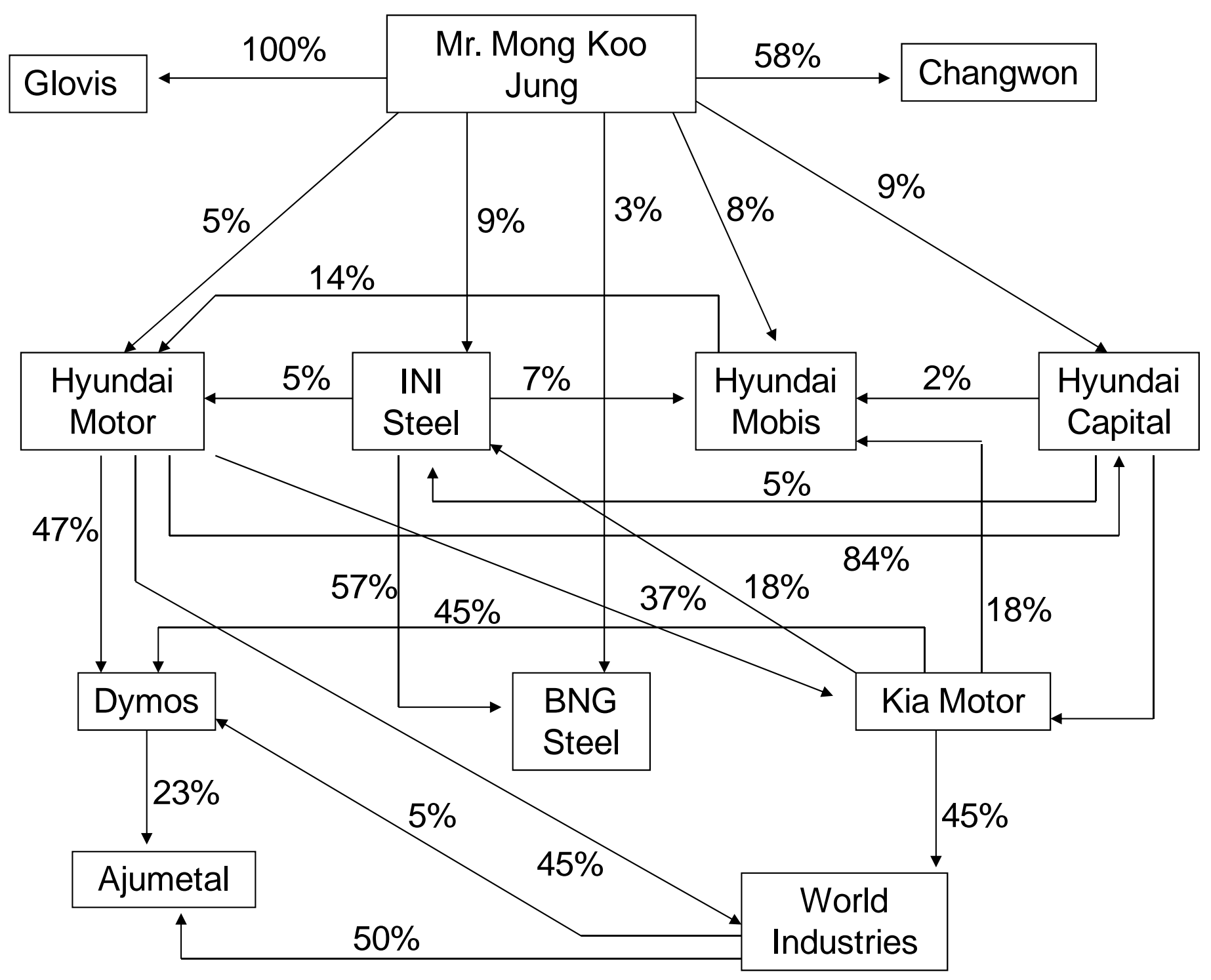


Figure 2. Average Ownership Structure of a Korean Chaebol, 1998-2004

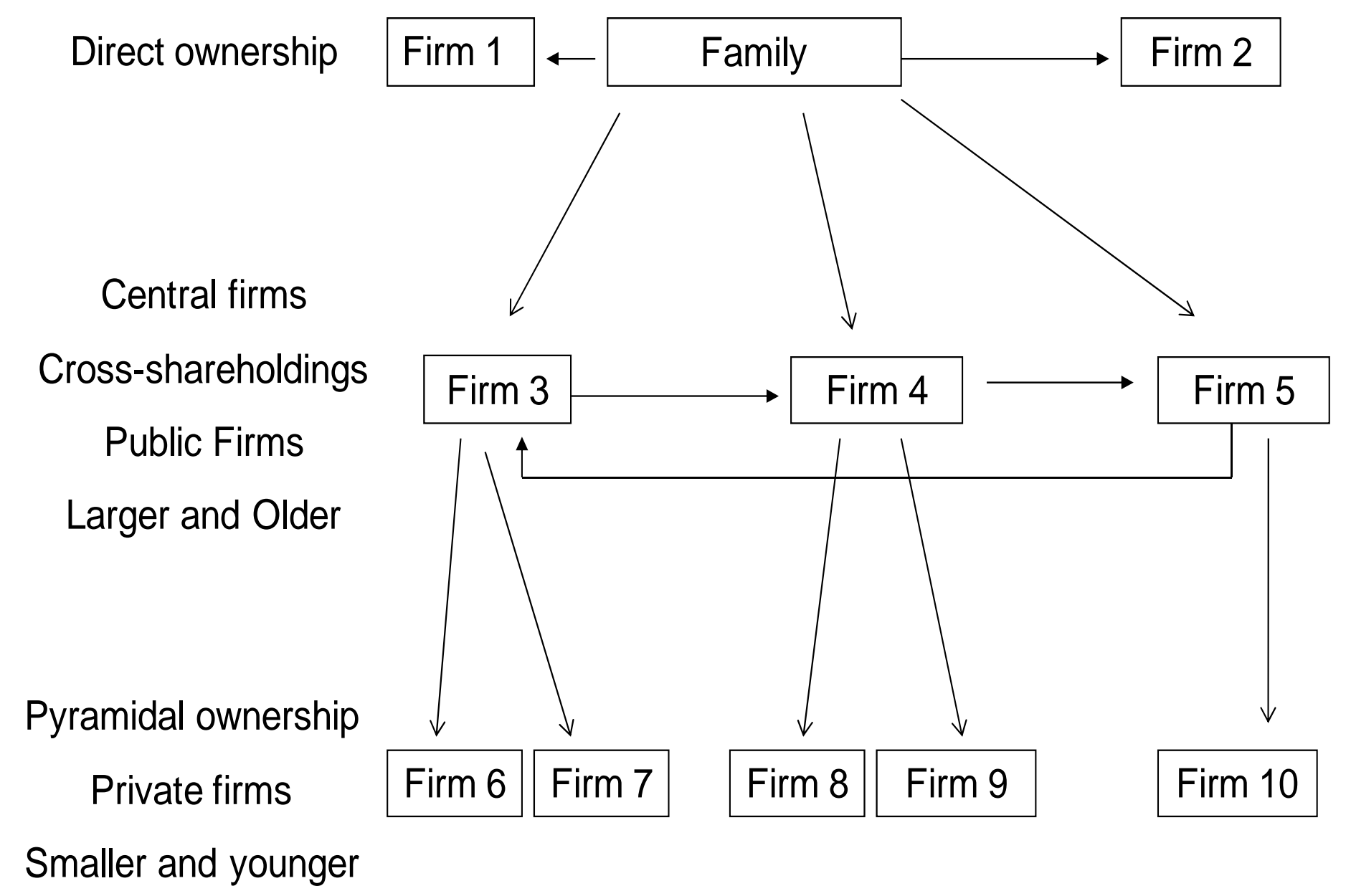

